\title{
Fuel Performance Annual Report for 1980
}

Prepared by W. J. Bailey, K. H. Rising/PNL

M. Tokar/USNRC

Pacific Northwest Laboratory

Operated by

Battelle Memorial Institute

Prepared for

U.S. Nuclear Regulatory

Commission 


\title{
NOTICE
}

This report was prepared as an account of work sponsored by an agency of the United States Government. Neither the United States Government nor any agency thereof, or any of their employees, makes any warranty, expressed or implied, or assumes any legal liability or responsibility for any third party's use, or the results of such use, of any information, apparatus product or process disclosed in this report, or represents that its use by such third party would not infringe privately owned rights.

\author{
Available from \\ GPO Sales Program \\ Division of Technical Information and Document Control \\ U. S. Nuclear Regulatory Commission \\ Washington, D. C. 20555 \\ Printed copy price: $\$ 4.75$
}

and 
NUREG/CR-2410

PNL-3953

\section{Fuel Performance Annual Report for 1980}

Manuscript Completed: November 1981

Date Published: December 1981

Prepared by

W. J. Bailey, K. H. Rising, Pacific Northwest Laboratory

M. Tokar, U.S. Nuclear Regulatory Cornmission

Pacific Northwest Laboratory

P. O. Box 999

Richland, WA 99352

\section{Prepared for}

Division of $S_{\}}$items Integration

Office of Nuclear Reactor Regulation

U.S. Nuclear Regulatory Commission

Washington, D.C. $<0555$

NRC FIN B2350 


\section{Availability of Reference Materials Cited in NAC Publications}

Most documents cited in NAC publications will be available from one of the following sources:

1. The NAC Public Document Room, 1717 H Street., N.W

Washington, DC 20555

2. The NRC/GPO Sales Program, U.S. Nuclear Regulatory Commission, Washington, DC 20555

3. The National Technical Information Service, Springfield, VA 22161

Although the listing that follows represents the majority of documents cited in NAC publications, it is not intended to be exhaustive.

Referenced documents available for inspection and copying for a fee from the NAC Public Document Room include NAC correspondence and internal NAC memoranda; NAC Office of Inspection and Enforce. ment bulletins, circulars, information notices, inspection and investigation notices; Licensee Event Reports; vendor reports and correspondence; Commission papers; and applicant and licensee documents and correspondence.

The following documents in the NUREG series are available for purchase from the NAC/GPO Sales Program: formal NAC staff and contractor reports, NAC-sponsored conference proceedings, and NAC booklets and brochures. Also available are Regulatory Guides, NRC regulations in the Code of Federal Regulations, and Nuclear Regulatory Commission issuances.

Documents available from the National Technical Information Service include NUREG series reports and technical reports prepared by other federal agencies and reports prepared by the Atomic Energy Commis. sion, forerunner agency to the Nuclear Regulatory Commission.

Documents available from public and special technical libraries include all open literature items, such as books, journal and periodical articles, transactions, and codes and standards. Federal Register notices, federal and state legislation, and congressional reports can usually be obtained from these libraries.

Documents such as theses, dissertations, foreign reports and translations, and non-NRC conference proceedings are available for purchase from the organization sponsoring the publication cited.

Single copies of NRC draft reports are available free upon written request to the Division of Technical Information and Document Control, U.S. Nuclear Regulatory Commission, Washington, DC 20555. 


\section{ABSTRACT}

This annual report, the third in a series, provides a brief description of fuel performance in commercial nuclear power plants. Brief summaries of fuel surveillance programs and operating experience, fuel performance probiems, and fuel design changes are provided. References to additional, more detailed, information and related NRC evaluation are included. 



\section{CONTENTS}

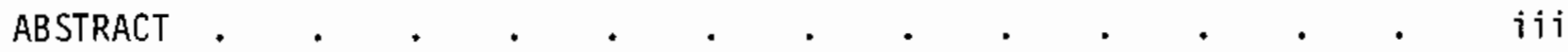

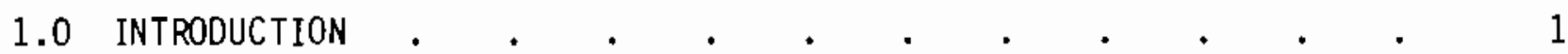

2.0 FUEL SURVEILLANCE PROGRAMS AND OPERATING EXPERIENCE $\quad$ • $\quad . \quad 3$

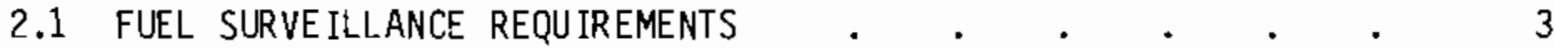

2.2 FUEL SURVEILLANCE PROGRAM AND EXPERIENCE SUMMARY • . • • 6

2.2.1 Babcock \& Wilcox Company $\quad$. $\quad$. $\quad$. . . . . 6

2.2.2 Combustion Engineering, Inc. . . . . . . 11

2.2.3 Exxon Nuclear Company, Inc. . . . . . . . 13

2.2.4 General Electric Company . . . . . . 16

2.2.5 Westinghouse Electric Corporation . . . 20

2.2.6 Electric Power Research Institute . . . . 24

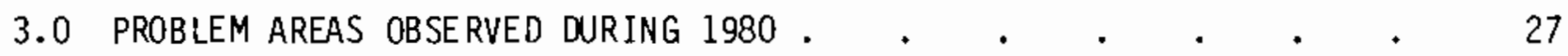

3.1 PROBLEMS IN 1980 THAT WERE SIMILAR TO THOSE IN 1979 • • 27

3.1.1 PWR Baffle Jetting . . . . . . . . 27

3.1.2 Westinghouse Grid Strap Damage . . . . . 28

3.1.3 Crud and Corrosion . . . . . . . . 29

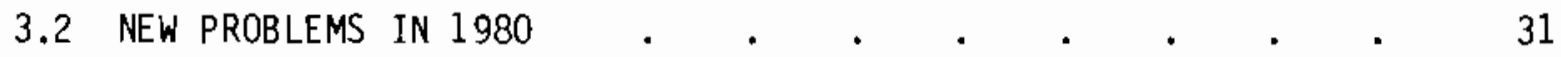

3.2.1 PWR Control Rod Guide Tube Support Pin Cracking . . $\quad 31$

3.2.2 Underpressurized Gadolinia Fuel Rods . . . . 32

3.2.3 PWR Hold-Down Spring Damage . . . . . . 33

3.2.4 Iodine Spiking . . . . . . . . . 35

3.2.5 Alpha Activity in Coolant . . . . . . 41

3.2.6 Misoriented Fuel Assemblies . . . . . . . 41

3.2 .7 Other Occurrences . . . . . . . . . . . 42 
3.3 OLO PROBLEMS (1979) THAT DIO NOT REOCCUR OR THAT WERE SOLVEO.

3.3.1 PWR Guide Tube Wear . . . . . . . 43

3.3.2 Westinghouse Control Spider Rodlet Failures . . 44

3.3.3 Other Problems in 1979 That Did Not Reoccur in 1980 . 44

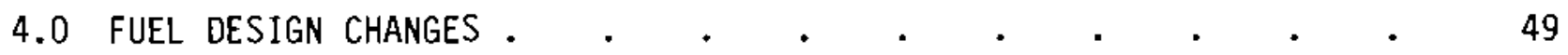

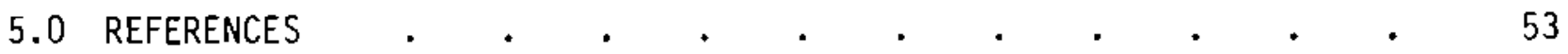




\section{TABLES}

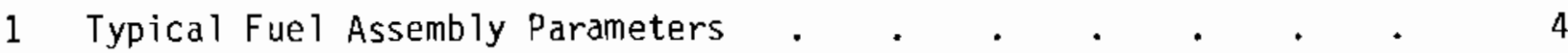

2 Major Fue 1 Performance Programs: Status Through 1980 . $\quad$. $\quad$ - 7

3 Summary of Babcock \& Wilcox Fuel Rod Performance for 1980 . . 8

4 Babcock \& Wilcox Operating Plant Status as of December 31, 1980 . 9

5 Summary of Combustion Engineering Fuel Irradiated and/or Discharged in 1980 . $\quad . \quad$. $\quad . \quad$. $\quad . \quad$. . . 12

6 Combustion Engineering Burnup Experience with All-ZircaloyAssemblies: Status as of December $31,1980 . \quad . \quad . \quad . \quad . \quad 14$

7 Typical Equilibrium Iodine-131 in the Primary Coolant of Combustion Engineering Reactors During 1980 . $. \quad . \quad$. . . 15

8 Summary of Exxon Nuclear Fuel Exposure in 1980 . $\quad$. . . . 17

9 General Electric BWR/2-5 Fuel Experience Summary . . . . . 18

1n Summary of Genera? Electric Lead Test Assembly and Extended
Bumup Bund les. . . . . . . . . . . . . . . 19

11 Westinghouse Zircaloy-Clad Fuel Burnup Status as of December 31,
1980: Assemblywise Bumup Distribution of Fue T Rods . . . 21

12 Westinghouse Fuel Performance Status Report . . . . . . . 22

13 Technical Specifications for Primary Coolant Activity . . . . 37 



\subsection{INTRODUCTION}

Important feedback for safety considerations and licensing procedures is produced by monitoring the in-reactor performance of nuclear fuel in commercial light-water power reactors. Members of the public, governing and adivsory bodies, and the U.S. Nuclear Regulatory Commission (NRC) staff have expressed interest in a publicly available summary of in-reactor fuel performance. As a result, a series of annual reports, of which this is the third, has been implemented to provide such a summary. The first was NUREG-0633 (Ref. 1), which covered the period through calendar year 1978. The second, NUREG/CR-1818 (PNL-3583) (Ref. 2), covered calendar year 1979.

The first report (Ref. 1) noted that the Atomic Energy Commission (AEC) and then the NRC have requested operating nuclear reactor fuel performance details through the reporting requirements of Regulatory Guide 1.16 (Ref. 3 ). However, over the years the material covered in these reports has changed. In the 1971 version of the guide, the NRC requested that a summary of fuel performance characteristics be included in semiannual operating reports and that special topical reports be used for fuel inspection details. By 1975 though, only the abnormal degradation of fuel cladding and the indication of failed fuel were reportable items. (a) The reporting requirements were further reduced in 1977: only abnormal degradation of fuel cladding was to be included and the requirement for an annual operating report was eliminated. Also, normal operation surveillance results, generic problems, and design

(a) A report published in 1981, NUREG/CR-1380 (PNL-3325) (Ref. 4), elaborates on the reporting of abnormal degradation and fuel failures. The threshold for what constitutes abnormal degradation is not uniform and remains a matter of opinion. Therefore, the degree of reported degradation is not uniform. The definition of failed fuel is tied to the functional, legal, and detection requirements on the fuel. The designation of fuel as fajled depends on which functional requirement is not met (safety, commercial, design), whether or not there is a legal contingency on that requirement (Technical Specification, fuel warranty, design basis), and which indicator is used (coolant or off-gas activity, sipping, strain, or deflection). Thus, the definition can vary from outage to outage and from reload to reload for each utility as the considerations change. 
trends are not addressed in the NUREG series of reports entitled "Nuclear Power Plant Operating Experience" (Refs. 5-10).

As a result, the primary intent of this report series is to identify on-going surveillance programs, summarize the results from those programs, and report on generic problems that are of concern during the reporting period. In preparing the reports, we attempt to provide a traceable path of references so that the reader can acquire a greater level of detail than is included in the annual summary.

This report, though focusing on fuel operating experience during calendar year 1980, includes some overlap with the previous year. For those problems first encountered prior to 1980, the pre-1980 information will be included for the sake of continuity. In addition, information received or action taken in early 1981 will be included if pertinent to the discussion of problem areas. 


\subsection{FUEL SURVEILLANCE PROGRAMS AND OPERATING EXPERIENCE}

Basic requirements of fue 1 surveillance programs, followed by a summary of current programs and operating experience, are presented in this section.

\subsection{FUEL SURVEILLANCE REQUIREMENTS}

It is indicated under Section 4.2, Fuel System Design, of the Standard Review Plan (Ref. 11) that plans for testing, inspection, and fuel surveillance should be submitted and reviewed for each domestic nuclear power plant. Such $\mathrm{plans}$ should include preirradiation verification of cladding integrity, fuel system dimensions, fuel enrichment, burnable poison concentration, and absorber composition. Postirradiation surveillance plans are dependent on whether the fuel design is an existing or new design, and if the fuel exhibited any unusual behavior or characteristics. These plans are then referenced and/or summarized in the plant's safety analysis report (SAR). Reference 12 is an example of a required fuel surveillance program.

Typical fuel assembly parameters ${ }^{(a)}$ and operating conditions for current commercial light-water reactor (LWR) fuel rod designs for use in pressurized water reactors (PWRs) and boiling water reactors (BWRs) are summarized in Table 1. The newer fuel rod designs are those with smaller fuel rod diameters and more fuel rods per assembiy. In a fuel assembly that employs fuel rods of a newer design, the total assembly power is maintained while the individual fue 1 rods are operated at lower linear heat generation rates and temperatures. This design change is expected to aid in improving the irradiation behavior of commercial LWR fuel by reducing fission gas release from the fuel and by reducing the mechanical interaction between the fuel and cladding. For example, sample calculations indicate that shift from a $7 \times 7$ to an $8 \times 8$ rod array in a BWR fuel assembly results in a reduction in fission gas release of about $15 \%$ at

(a) The terms "fuel assembly" and "fuel bundle" are used interchangeably by the nuclear industry. Generally the former term is associated with fuel for PWRs and the latter term with fuel for BWRs. 
TABLE 1. Typical Fuel Assembly Parameters

\begin{tabular}{|c|c|c|c|c|c|c|c|c|c|c|c|c|}
\hline VENDOR & B\&W & B\&W & $C-E$ & $\mathrm{C}-\mathrm{E}$ & $\underline{W}$ & $\stackrel{W}{*}$ & $\underline{W}$ & ENC & ENC & $\mathrm{GE}$ & $\mathrm{GE}$ & $\mathrm{GE}$ \\
\hline Fue 1 Rod Array & $15 \times 15$ & $17 \times 17$ & $14 \times 14$ & $16 \times 16$ & $14 \times 14$ & $15 \times 15$ & $17 \times 17$ & $15 \times 15$ & $8 \times 8$ & $7 \times 7$ & $8 \times 8$ & $8 \times 8 R$ \\
\hline Reactor Type & PWR & PWR & PWR & PWR & PWR & PWR & PWR & PWR & $B W R$ & $B W R$ & BWR & BWR \\
\hline Assemblies per Core & 177 & 205 & 217 & 177 & 121 & 193 & 193 & 193 & 560 & 764 & 560 & 560 \\
\hline $\begin{array}{l}\text { Fuel Rod Locations } \\
\text { Per Assembly }\end{array}$ & 225 & 289 & 196 & 256 & 196 & 225 & 289 & 225 & 64 & 49 & 64 & 64 \\
\hline $\begin{array}{l}\text { Fuel Rods } \\
\text { Per Assembly }\end{array}$ & 208 & 264 & 176 & 236 & 179 & 204 & 264 & 204 & 60 & 49 & 63 & 62 \\
\hline $\begin{array}{l}\text { Empty Locations } \\
\text { Per Assembly }\end{array}$ & 17 & 25 & 5 & 5 & 17 & 21 & 25 & 21 & 4 & NONE & 1 & 2 \\
\hline $\begin{array}{l}\text { Rod Pitch, } \\
\lim (i n .)\end{array}$ & $\begin{array}{l}14.4 \\
(0.568)\end{array}$ & $\begin{array}{l}12.7 \\
(0.501)\end{array}$ & $\begin{array}{l}14.7 \\
(0.580)\end{array}$ & $\begin{array}{l}12.9 \\
(0.5063)\end{array}$ & $\begin{array}{l}14.1 \\
(0.556)\end{array}$ & $\begin{array}{l}14.3 \\
(0.563)\end{array}$ & $\begin{array}{l}12.6 \\
(0.496)\end{array}$ & $\begin{array}{l}14.3 \\
(0.563)\end{array}$ & $\begin{array}{l}16.3 \\
(0.842)\end{array}$ & $\begin{array}{l}18.7 \\
(0.738)\end{array}$ & $\begin{array}{l}16.3 \\
(0.640)\end{array}$ & $\begin{array}{l}16.3 \\
(0.640)\end{array}$ \\
\hline $\begin{array}{l}\text { System Pressure, } \\
M P_{A} \text { (psia) }\end{array}$ & $\begin{array}{l}15.2 \\
(2200)\end{array}$ & $\begin{array}{l}15.5 \\
(2250)\end{array}$ & $\begin{array}{l}15.5 \\
(2250)\end{array}$ & $\begin{array}{l}15.5 \\
(2250)\end{array}$ & $\begin{array}{l}15.5 \\
(2250)\end{array}$ & $\begin{array}{l}15.5 \\
(2250)\end{array}$ & $\begin{array}{l}15.5 \\
(2250)\end{array}$ & $\begin{array}{l}15.5 \\
(2250)\end{array}$ & $\begin{array}{l}7.14 \\
(1035)\end{array}$ & $\begin{array}{l}7.14 \\
(1035)\end{array}$ & $\begin{array}{l}7.14 \\
(1035)\end{array}$ & $\begin{array}{l}7.14 \\
(1035)\end{array}$ \\
\hline $\begin{array}{l}\text { Core Average Power } \\
\text { Density, kw/liter }\end{array}$ & 91.4 & 107.3 & 78.5 & 96.4 & 95.6 & 98.1 & 104.7 & 98.1 & 40.57 & 50.732 & 50.51 & 49.15 \\
\hline $\begin{array}{l}\text { Average LHGR, (a) } \\
\mathrm{kW} / \mathrm{M}(\mathrm{kW} / \mathrm{ft})\end{array}$ & $\begin{array}{l}20.3 \\
(6.20)\end{array}$ & $\begin{array}{l}18.8 \\
(5.73)\end{array}$ & $\begin{array}{l}20.0 \\
(6.09)\end{array}$ & $\begin{array}{l}17.5 \\
(5.34)\end{array}$ & $\begin{array}{l}20.3 \\
(6.20)\end{array}$ & $\begin{array}{l}22.0 \\
(6.70)\end{array}$ & $\begin{array}{l}17.8 \\
(5.44)\end{array}$ & $\begin{array}{l}22.0 \\
(6.70)\end{array}$ & $\begin{array}{l}15.2 \\
(4.63)\end{array}$ & $\begin{array}{l}23.1 \\
(7.049)\end{array}$ & $\begin{array}{l}17.9 \\
(5.45)\end{array}$ & $\begin{array}{l}17.7 \\
(5.38)\end{array}$ \\
\hline $\begin{array}{l}\text { Axidl Peak LHGR, } \\
\text { in an Average Rod, } \\
W / M(k w / f t)\end{array}$ & $\begin{array}{l}24.41 \\
(7.44)\end{array}$ & $\begin{array}{l}22.57 \\
(6.88)\end{array}$ & $\begin{array}{l}24.00 \\
(7.31)\end{array}$ & $\begin{array}{l}21.00 \\
(6.41)\end{array}$ & $\begin{array}{l}24.36 \\
(7.44)\end{array}$ & $\begin{array}{l}26.40 \\
(8.04)\end{array}$ & $\begin{array}{l}21.36 \\
(6.53)\end{array}$ & $\begin{array}{l}26.40 \\
(8.04)\end{array}$ & $\begin{array}{l}18.24 \\
(6.02)\end{array}$ & $\begin{array}{l}27.72 \\
(9.16)\end{array}$ & $\begin{array}{l}21.48 \\
(7.09)\end{array}$ & $\begin{array}{l}21.24 \\
(6.99)\end{array}$ \\
\hline $\begin{array}{l}\text { Max. Peak LHGR, } \\
\mathrm{kW} / \mathrm{M}(\mathrm{kW} / \mathrm{ft})\end{array}$ & $\begin{array}{l}53.0 \\
(16.16)\end{array}$ & $\begin{array}{l}49.9 \\
(15.20)\end{array}$ & $\begin{array}{l}53.5 \\
(16.3)\end{array}$ & $\begin{array}{l}42.7 \\
(13.0)\end{array}$ & $\begin{array}{l}56.8 \\
(17.3)\end{array}$ & $\begin{array}{l}61.7 \\
(18.8)\end{array}$ & $\begin{array}{l}44.6 \\
(13.6)\end{array}$ & $\begin{array}{l}51.9 \\
(15.83)\end{array}$ & $\begin{array}{l}47.6 \\
(14.5)\end{array}$ & $\begin{array}{l}60.2 \\
(18.35)\end{array}$ & $\begin{array}{l}44.0 \\
(13.4)\end{array}$ & $\begin{array}{l}44.0 \\
(13.4)\end{array}$ \\
\hline $\begin{array}{l}\text { Max. Fue } 1 \text { Temp. } \\
{ }_{0} C \text { (of) }\end{array}$ & $\begin{array}{l}2340 \\
(4245)\end{array}$ & $\begin{array}{l}2090 \\
(4155)\end{array}$ & $\begin{array}{l}2140 \\
(3890)\end{array}$ & $\begin{array}{l}1880 \\
(3420)\end{array}$ & $\begin{array}{l}2260 \\
(4100)\end{array}$ & $\begin{array}{l}2340 \\
(4250)\end{array}$ & $\begin{array}{l}1870 \\
(3400)\end{array}$ & $\begin{array}{l}2200 \\
(3997)\end{array}$ & $\begin{array}{l}2040 \\
(3700)\end{array}$ & $\begin{array}{l}2440 \\
(4430)\end{array}$ & $\begin{array}{l}1830 \\
(3325)\end{array}$ & $\begin{array}{l}1890 \\
(3435)\end{array}$ \\
\hline $\begin{array}{l}\text { Core Average } \\
\text { Enrichment, } \\
\text { wt\% } 235 \mathrm{v}\end{array}$ & 3.00 & 2.67 & 2.35 & 2.36 & 2.90 & 2.80 & 2.60 & 3.02 & 2.65 & 2.19 & 1.80 & 1.99 \\
\hline $\begin{array}{l}\text { Max. Local } \\
\text { Exposure } \\
\text { MWd/MTU(b) } \\
\text { GJ/kgu(c) }\end{array}$ & $\begin{array}{l}55,000 \\
4752\end{array}$ & $\begin{array}{l}55,000 \\
4752\end{array}$ & $\begin{array}{l}50,000 \\
4320\end{array}$ & $\begin{array}{l}55,000 \\
4752\end{array}$ & $\begin{array}{l}50,000 \\
4320\end{array}$ & $\begin{array}{l}50,000 \\
4320\end{array}$ & $\begin{array}{l}50,000 \\
4320\end{array}$ & $\begin{array}{l}47,500 \\
4104\end{array}$ & $\begin{array}{l}35,000 \\
3024\end{array}$ & $\begin{array}{l}40,000 \\
3456\end{array}$ & $\begin{array}{l}40,000 \\
3456\end{array}$ & $\begin{array}{l}45,000 \\
3888\end{array}$ \\
\hline $\begin{array}{l}\text { Cladding } \\
\text { Material }\end{array}$ & Zry-4 & Zry-4 & Zry -4 & Zry-4 & $2 r y-4$ & $2 r y-4$ & $2 r y-4$ & Zry-4 & $2 r y-2$ & Zry -2 & $\operatorname{Zry}-2$ & Zry-2 \\
\hline
\end{tabular}




\section{TABLE 1. (contd)}

\begin{tabular}{|c|c|c|c|c|c|c|c|c|c|c|c|c|}
\hline VENDOR & BEH & B\&W & $C-E$ & $C-E$ & $\underline{w}$ & $\underline{W}$ & $\underline{\underline{w}}$ & ENC & $\mathrm{ENC}$ & GE & $\mathrm{GE}$ & $\mathrm{GE}$ \\
\hline $\begin{array}{l}\text { Fuel Rod } \\
\text { Length, } \\
\text { m(in.) }\end{array}$ & $\begin{array}{l}3.904 \\
(153.688)\end{array}$ & $\begin{array}{l}3.864 \\
(152.125)\end{array}$ & $\begin{array}{l}3.71 \\
(145.9)\end{array}$ & $\begin{array}{l}4.09 \\
(161.02)\end{array}$ & $\begin{array}{l}3.87 \\
(152.36)\end{array}$ & $\begin{array}{l}3.80 \\
(149.7)\end{array}$ & $\begin{array}{l}3.85 \\
(151.6)\end{array}$ & $\begin{array}{l}3.86 \\
(152.0)\end{array}$ & $\begin{array}{l}3.99 \\
(156.92)\end{array}$ & $\begin{array}{l}4.09 \\
(161.1)\end{array}$ & $\begin{array}{l}4.09 \\
(161.1)\end{array}$ & $\begin{array}{l}4.20 \\
(185.4)\end{array}$ \\
\hline $\begin{array}{l}\text { Active Fuel } \\
\text { Height, } \\
m \text { (in.) }\end{array}$ & $\begin{array}{l}3.602 \\
(141.8)\end{array}$ & $\begin{array}{l}3.632 \\
(143)\end{array}$ & $\begin{array}{l}3.47 \\
(136.7)\end{array}$ & $\begin{array}{l}3.81 \\
(150)\end{array}$ & $\begin{array}{l}3.66 \\
(144)\end{array}$ & $\begin{array}{l}3.66 \\
(144)\end{array}$ & $\begin{array}{l}3.65 \\
(143.7)\end{array}$ & $\begin{array}{l}3.66 \\
(144)\end{array}$ & $\begin{array}{l}3.66 \\
(144)\end{array}$ & $\begin{array}{l}3.66 \\
(144)\end{array}$ & $\begin{array}{l}3.71 \\
(146)\end{array}$ & $\begin{array}{l}3.81 \\
(150)\end{array}$ \\
\hline $\begin{array}{l}\text { Plenum Length, } \\
\text { m (in.) }\end{array}$ & $\begin{array}{l}0.298 \\
(11.27)\end{array}$ & $\begin{array}{l}0.242 \\
(9.52)\end{array}$ & $\begin{array}{l}0.22 \\
(8.6)\end{array}$ & $\begin{array}{l}0.25 \\
(10.00)\end{array}$ & $\begin{array}{l}0.18 \\
(6.99)\end{array}$ & $\begin{array}{l}0.21 \\
(8.2)\end{array}$ & $\begin{array}{l}0.16 \\
(6.3)\end{array}$ & $\begin{array}{l}0.17 \\
(6.8)\end{array}$ & $\begin{array}{l}0.27 \\
(10.63)\end{array}$ & $\begin{array}{l}0.41 \\
(16.0)\end{array}$ & $\begin{array}{l}0.36 \\
(14.0)\end{array}$ & $\begin{array}{l}0.25 \\
(10.0)\end{array}$ \\
\hline $\begin{array}{l}\text { Fue } 1 \text { Rod OD, } \\
\text { mm (in.) }\end{array}$ & $\begin{array}{l}10.922 \\
(0.430)\end{array}$ & $\begin{array}{l}9.627 \\
(0.379)\end{array}$ & $\begin{array}{l}11.18 \\
(0.440)\end{array}$ & $\begin{array}{l}9.70 \\
(0.382)\end{array}$ & $\begin{array}{l}10.72 \\
(0.422)\end{array}$ & $\begin{array}{l}10.72 \\
(0.422)\end{array}$ & $\begin{array}{l}9.50 \\
(0.374)\end{array}$ & $\begin{array}{l}10.77 \\
(0.424)\end{array}$ & $\begin{array}{l}12.74 \\
(0.5015)\end{array}$ & $\begin{array}{l}14.30 \\
(0.563)\end{array}$ & $\begin{array}{l}12.52 \\
(0.493)\end{array}$ & $\begin{array}{l}12.27 \\
(0.483)\end{array}$ \\
\hline $\begin{array}{l}\text { Cladding } 10, \\
\mathrm{~m} \text { (in.) }\end{array}$ & $\begin{array}{l}9.576 \\
(0.377)\end{array}$ & $\begin{array}{l}8.407 \\
(0.331)\end{array}$ & $\begin{array}{l}9.86 \\
(0.388)\end{array}$ & $\begin{array}{l}8.43 \\
(0.332)\end{array}$ & $\begin{array}{l}9.48 \\
(0.3734)\end{array}$ & $\begin{array}{l}9.48 \\
(0.3734)\end{array}$ & $\begin{array}{l}8.36 \\
(0.329)\end{array}$ & $\begin{array}{l}9.25 \\
(0.364)\end{array}$ & $\begin{array}{l}10.91 \\
(0.4295)\end{array}$ & $\begin{array}{l}12.68 \\
(0.499)\end{array}$ & $\begin{array}{l}10.80 \\
(0.425)\end{array}$ & $\begin{array}{l}10.64 \\
(0.419)\end{array}$ \\
\hline $\begin{array}{l}\text { Cladding } \\
\text { Thickness, } \\
\text { min (in.) }\end{array}$ & $\begin{array}{l}0.673 \\
(0.0265)\end{array}$ & $\begin{array}{l}0.610 \\
(0.0240)\end{array}$ & $\begin{array}{l}0.660 \\
(0.026)\end{array}$ & $\begin{array}{l}0.635 \\
(0.025)\end{array}$ & $\begin{array}{l}0.617 \\
(0.0243)\end{array}$ & $\begin{array}{l}0.617 \\
(0.0243)\end{array}$ & $\begin{array}{l}0.572 \\
(0.0225)\end{array}$ & $\begin{array}{l}0.762 \\
(0.030)\end{array}$ & $\begin{array}{l}0.914 \\
(0.036)\end{array}$ & $\begin{array}{l}0.813 \\
(0.032)\end{array}$ & $\begin{array}{l}0.864 \\
(0.034)\end{array}$ & $\begin{array}{l}0.813 \\
(0.032)\end{array}$ \\
\hline $\begin{array}{l}\text { Diametral Gap, } \\
\text { micron (mil) }\end{array}$ & $\begin{array}{l}213.4 \\
(8.4)\end{array}$ & $(7.8)$ & $\begin{array}{l}216 \\
(8.5)\end{array}$ & $\begin{array}{l}178 \\
(7.0)\end{array}$ & $\begin{array}{l}190 \\
(7.5)\end{array}$ & $\begin{array}{l}190 \\
(7.5)\end{array}$ & $\begin{array}{l}165 \\
(6.5)\end{array}$ & $\begin{array}{l}190 \\
(7.5)\end{array}$ & $\begin{array}{l}254 \\
(10.0)\end{array}$ & $\begin{array}{l}305 \\
(12.0)\end{array}$ & $\begin{array}{l}229 \\
(9.0)\end{array}$ & $\begin{array}{l}229 \\
(9.0)\end{array}$ \\
\hline $\begin{array}{l}\text { Fue } 1 \text { Pellet } \\
\text { Oiameter, } \\
\text { im (in.) }\end{array}$ & $\begin{array}{l}9.362 \\
(0.3686)\end{array}$ & $\begin{array}{l}8.209 \\
(0.3232)\end{array}$ & $\begin{array}{l}9.64 \\
(0.3795)\end{array}$ & $\begin{array}{l}8.26 \\
(0.325)\end{array}$ & $\begin{array}{l}9.29 \\
(0.3659)\end{array}$ & $\begin{array}{l}9.29 \\
(0.3659)\end{array}$ & $\begin{array}{l}8.19 \\
(0.3225)\end{array}$ & $\begin{array}{l}9.06 \\
(0.3565)\end{array}$ & $\begin{array}{l}10.66 \\
(0.4195)\end{array}$ & $\begin{array}{l}12.37 \\
(0.487)\end{array}$ & $\begin{array}{l}10.57 \\
(0.416)\end{array}$ & $\begin{array}{l}10.41 \\
(0.410)\end{array}$ \\
\hline $\begin{array}{l}\text { Fue } 1 \text { Pellet } \\
\text { Length, } \\
\text { m (in.) }\end{array}$ & $\begin{array}{l}15.240 \\
(0.600)\end{array}$ & $\begin{array}{l}9.525 \\
(0.375)\end{array}$ & $\begin{array}{l}16.51 \\
(0.650)\end{array}$ & $\begin{array}{l}9.91 \\
(0.390)\end{array}$ & $\begin{array}{l}15.24 \\
(0.600)\end{array}$ & $\begin{array}{l}15.24 \\
(0.600)\end{array}$ & $\begin{array}{l}13.46 \\
(0.530)\end{array}$ & $\begin{array}{l}6.93 \\
(0.273)\end{array}$ & $\begin{array}{l}8.13 \\
(0.320)\end{array}$ & $\begin{array}{l}12.70 \\
(0.500)\end{array}$ & $\begin{array}{l}10.67 \\
(0.420)\end{array}$ & $\begin{array}{l}10.41 \\
(0.410)\end{array}$ \\
\hline $\begin{array}{l}\text { Fue } 1 \text { Pellet } \\
\text { Density, , STD }\end{array}$ & 95 & 95 & 94.75 & 95 & 94 & 95 & 95 & 94 & 95 & 95 & 95 & 95 \\
\hline
\end{tabular}


high burnups (e.g., the release value drops from $26 \%$ to $13 \%$ at $30,000 \mathrm{MWd} / \mathrm{MTU}$ and from $46 \%$ to $30 \%$ at $45,000 \mathrm{MNd} / \mathrm{MTU}$ ). (a)

\subsection{FUEL SURVEILLANCE PROGRAM AND EXPERIENCE SUMMARY}

Table 2 contains an up-dated listing of the major fuel surveillance programs for each fuel vendor. Additional information on the programs and on a number of the associated fuel design changes is provided in Section 4.0. Depending on the program, nondestructive and/or destructive examination techniques are used. Some of these programs are jointly sponsored with participation by the fuel vendor, utility, utility groups, and the Electric Power Research Institute (EPRI). Listing of a given program under a vendor heading is not, therefore, intended to imply that that vendor is the sole sponsor. Project details shown in Table 2 reflect the NRC's current understanding of the programs and are subject to change. The following subsections provide a brief synopsis of each vendor's program and EPRI's invoivement.

\subsubsection{Babcock \& Wilcox Company (B\&W)}

A summary of Babcock \& Wilcox fuel rod experience, from the startup of their first reactor (Oconee-1) in April 1973 through December 1980 is shown in Table 3 (Ref. 13), which shows that over 587,000 fuel rods have been irradiated. A total of 305,568 fuel rods were irradiated in 1980. (b) While B\&W has reported relatively good fuel performance, several plants issued Licensee Event Reports in 1980 on iodine spiking (see Section 3.2.4), which implies that fuel rod failures are associated with those events.

(a) MNd/MTU = number of megawatt days of thermal energy released by fuel containing one metric ton $\left(10^{6} \mathrm{~g}\right)$ of heavy-metal atoms (e.g., $U=$ uranium).

(b) The fuel information by B\&W for the previous annual report (Ref. 2) showed the following: 1) 94 leaker rods were estimated to be in cores at the end of 1979 (that number was subsequently revised downward to 78 as shown in Table 3), 2) 333,440 rods were irradiated and 80 leaker rods were estimated to have been generated in 1979, and 3) the number of leaker rods in cores at the end of 1978 was estimated to be 49 . Leaker refers to a fue 1 rod that is releasing fision products to the reactor coolant through a breach in its cladding (Ref. 13). 
TABLE 2. Major Fuel Performance Programs: Status Through 1980

\begin{tabular}{|c|c|c|c|c|c|}
\hline Vendor & Fuel Type(a) & Power Plant & $\begin{array}{l}\text { Planned } \\
\text { No. of } \\
\text { Operating } \\
\text { Cycles } \\
\end{array}$ & $\begin{array}{l}\text { Scheduled } \\
\text { Completion }\end{array}$ & $\begin{array}{c}\text { Interim } \\
\text { Inspections } \\
\text { To Date }\end{array}$ \\
\hline Babcock \& Wilcox & $\begin{array}{l}15 \times 15 \\
15 \times 15(\mathrm{~b}) \\
15 \times 15(\mathrm{~d}) \\
15 \times 15(\mathrm{e}) \\
15 \times 15(\mathrm{f}) \\
15 \times 15(\mathrm{~g}) \\
17 \times 17 \text { (LTAS) }\end{array}$ & $\begin{array}{l}\text { Oconee-1 } \\
\text { Arkansas-1(c) } \\
\text { Rancho Seco } \\
\text { Oconee }-2 \\
\text { Oconee }-2 \\
\text { Oconee-2 } \\
\text { Oconee-2 }\end{array}$ & $\begin{array}{l}5 \\
3 \\
3 \\
4 \\
3 \\
3 \\
3\end{array}$ & $\begin{array}{l}1983 \\
1990 \\
1986 \\
1980 \\
1981 \\
1985 \\
1981\end{array}$ & $\begin{array}{l}2 \\
\text { None } \\
\text { None } \\
\text { Completed } \\
3 \\
\text { None } \\
3\end{array}$ \\
\hline $\begin{array}{l}\text { Combust ion } \\
\text { Engineer ing }\end{array}$ & $\begin{array}{l}14 \times 14 \\
14 \times 14 \\
14 \times 14 \\
16 \times 16 \\
16 \times 16\end{array}$ & $\begin{array}{l}\text { Calvert Cliffs-1 } \\
\text { Fort Calhoun } \\
\text { Fort Calhoun } \\
\text { Arkansas }-2(h) \\
\text { Arkansas-2 }\end{array}$ & 5 & $\begin{array}{l}1982 \\
1982 \\
1983 \\
1984\end{array}$ & Completed \\
\hline Exxon Nuclear & $\begin{array}{l}15 \times 15 \\
8 \times 8 \\
8 \times 8 \\
\text { rods }\end{array}$ & $\begin{array}{l}\text { H. B. Robinson-2 } \\
\text { Oyster Creek } \\
\text { Oyster Creek } \\
\text { Big Rock Point }\end{array}$ & & $\begin{array}{l}1980 \\
1979 \\
1983 \\
1982\end{array}$ & Completed \\
\hline General Electr ic & $\begin{array}{l}7 \times 7 \text { (MO2) } \\
8 \times 8 \text { (LTAS) } \\
8 \times 8 \text { (LTAS) } \\
8 \times 8 R \text { (LTAS) } \\
8 \times 8 R \text { (LTAs) } \\
\text { LTAs } \\
\text { LTAs (barrier cladding) } \\
\text { LTAs (extended burnup) }\end{array}$ & $\begin{array}{l}\text { Quad Cities-1 } \\
\text { Mont icello } \\
\text { Quad-Cities-1 } \\
\text { Peach Bottom-2 } \\
\text { Vermont Yankee } \\
\text { Quad Cities-1 } \\
\text { Quad Cities-1 } \\
\text { Mont icello }\end{array}$ & $\begin{array}{l}5 \\
4 \\
4 \\
5 \\
5 \\
1 \\
5\end{array}$ & $\begin{array}{l}1982 \\
1983 \\
1982\end{array}$ & $\begin{array}{l}\text { (i) } \\
\text { (i) }\end{array}$ \\
\hline Hest inghouse & 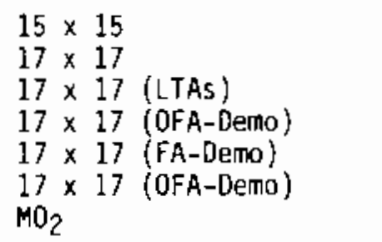 & $\begin{array}{l}\text { Zion-1/2ion-2 } \\
\text { Trojan } \\
\text { Surry-2 } \\
\text { Farley-1 } \\
\text { Salem-2 } \\
\text { Beaver Valley-1 } \\
\text { R. E. Ginna }\end{array}$ & $\begin{array}{l}5 \\
5 \\
4\end{array}$ & $\begin{array}{l}1984 \\
1984 \\
1981\end{array}$ & \\
\hline
\end{tabular}

(a) LTA = lead test assembly, $\mathrm{MO}_{2}=$ mixed oxide $\left(\mathrm{UO}_{2}-\mathrm{PuO}_{2}\right)$ fuel, $\mathrm{R}=$ retrofit fuel design, OFA-Demo = Demonstration Opt imized Fuel Assemblies.

(b) Lead test assemblies of an advanced $15 \times 15$ extended burnup design.

(c) Arkansas Nuclear Dne-Unit 1 (Arkansas-1)

(d) Current-design $15 \times 15$ assemblies containing axially-blanketed fuel columns.

(e) Current-design $15 \times 15$ assemblies with special Zircaloy cladding materials and EPRI creep collapse specimen clusters.

(f) Current-design $15 \times 15$ assemblies with lifted rods and cladding having a known spiral eccentricity.

(g) Current-design $15 \times 15$ assemblies utilizing low absorption spacer grid material (Zircaloy-4).

(h) Arkansas Nuc lear One-Unit 2 (Arkansas-2)

(i) The fuel bundles are now discharged. 


\section{TABLE 3. Summary of Babcock \& Wilcox Fuel Rod Performance for 1980(a)}

\section{Fuel Rod Type}

1. Cumulative Number of Rods Irradiated Through Dec. 1980:

a. Maximum Rod-Average Burnup, MWd/MTU

b. Mean Rod-Average Burnup, MWd/MTU

2. Total Number of Rods Irradiated in 1980

3. Number of Irradiated Rods In-Core on Dec. 31, 1980:

a. Maximum Rod-Average Burnup, MWd/MTU

b. Mean Rod-Average Burnup, MWd/MTU

4. Number of Rods Discharged in 1980:

a. Maximum Rod-Average Burnup, Mwd/MTU

b. Mean Rod-Average Burnup, MWd/MTU

5. Estimated Number of $(b)$ Leaker Rods:

a. In-Core on Jan. 1, 1980

b. Discharged in 1980

c. In-Core on Dec. 31,1980

d. Generated in 1980

e. Cumulative through Dec. 1980

$\begin{array}{rr}\frac{15 \times 15}{586,054} & \frac{17 \times 17}{1,056} \\ 41,600 & 28,210 \\ 18,650 & 26,560 \\ 304,512 & 1,056 \\ 266,448 & 528 \\ 32,430 & 28,210 \\ 14,740 & 27,130 \\ 61,360 & 528 \\ 39,240 & 27,940 \\ 24,900 & 26,000\end{array}$

$$
78(\mathrm{c})
$$$$
10
$$$$
77
$$$$
9
$$

(a) Connecticut Yankee (Haddam Neck) and Three Mile Island-Unit 2 (TMI-2) are excluded from this tabulation.

(b) Estimated from equilibrium coolant radio-iodine behavior during full-power operation (iodine-131, iodine-133, and iodine-135 activity levels). The relatively small percentage of $17 \times 17$ type type fuel (LTAs) operating with $15 \times 15$ type fue 1 precludes differentiation of probable leakers among the two fuel types.

(c) Revised from the value reported for Dec. 31, 1979, in NUREG/CR-1818 PNL-3583. The revised value is based upon identification of leaker assemblies in one reactor and correcting for their above-average power density. 
With the exception of fuel rods in four lead test assemblies (LTAS), the majority of the fuel rods irradiated were in fuel assemblies of the standard, $15 \times 15$, Mark B design. The operating status (as of December 31,1980 ) for $8 \& W$ plants is listed in Table 4 (Ref. 13). The relatively small fraction of $17 \times 17$ type fuel (LTAs) operating with the $15 \times 15$ type fuel precludes differentiation of probable leakers among the two fuel types. The number of leaker rods was estimated by $B \& W$ from the equilibrium coolant radioiodine (iodine-131, iodine-133, and iodine-135) behavior during full-power operation. Because of the uncertainties associated with the location and nature of probable leakers, the number of leaker rods stated in Table 3 represents a best-est imate of the status of fue : rod integrity.

The $B \& W$ method of coolant radioactivity analysis to assess the leaker level of operating fuel is described in Reference 14. In applying this method, on ly data obtained during conditions of equilibrium-iodine, full power operation are considered. Also, it is assumed that the leaker fuel rods are operating at core average conditions and that the plant purification system is operating at a known constant condition. Although these assumptions are

TABLE 4. Babcock \& Wilcox Operating Plant Status as of December 31,1980

\begin{tabular}{|c|c|c|c|}
\hline \multirow[b]{2}{*}{ Reactor } & \multirow{2}{*}{$\begin{array}{l}\text { Current } \\
\text { Cycle } \\
\end{array}$} & \multicolumn{2}{|c|}{$\begin{array}{l}\text { Maximum Assemb ly } \\
\text { Burnup, MWd/MTU }\end{array}$} \\
\hline & & In core & Discharged \\
\hline Oconee-1 & 6 & 26,300 & 40,000 \\
\hline Oconee-2 & 5 & 26,100 & 33,700 \\
\hline Oconee-3 & 5 & 23,900 & 31,940 \\
\hline $\operatorname{TMI-1}(\mathrm{a})$ & 4 & 32,400 & 32,200 \\
\hline Arkansas-1 ${ }^{\text {(b) }}$ & 4 & 30,740 & 33,220 \\
\hline Rancho Seco & 4 & 31,180 & 37,730 \\
\hline Crystal River -3 & 3 & 20,870 & 22,390 \\
\hline Dav is-Besse- 1 & 2 & 16,960 & 14,780 \\
\hline
\end{tabular}

(a) Cycle 5 start-up activities at Three Mile Island, Unit 1 (TMI-1) were terminated on March 30, 1979. The unit has remained in cold shut-down.

(b) Arkansas Nuclear One-Unit 1 (Arkansas-1). 
generally valid, errors can result if the local heat rate in the leaker rods is above or below the core averaqe. Thus, uncertainties in the location of the leaker rods, the nature of the cladding defects and their axial location along a rod preclude making an absolute correlation of coolant activity levels to the number of leaking rods in any one batch. However, B\&w believes that, on the average, the leaker correlation provides a useful indication of fuel performance to date. In all sipping tests and visua? examinations conducted to date, the radiochemistry projections reportedly correlate well with observed results. Consequently, B\&W feels that the leaker estimates are correct.

More specific information on the number of leaker rods was not available for this report because fuel assembly leak testing (sipping) was performed at only one reactor site, Rancho Seco, in 1980. Of 60 fuel assemblies discharged from Rancho Seco after three cycles, 43 were sipped as part of the "Load Following and Fuel Sipping Program" conducted jointly by NucTear Fuel Industry Limited of Japan, the Sacramento Municipal Utility District, and B\&w. Sipping (using the wet technique) was conducted during the refueling outage at the end of cycle 3 to verify the fuel cladding integrity of three-cycle fuel assemblies that were in the core during periods in which Rancho Seco operated in a loadfollow mode. Only one assembly was identified as a leaker. Only one leaker rod on the periphery of that assembly was identified by subsequent visual inspection of 1400 peripheral rods in 25 fuel assemblies (Refs. 13 and 15). $V$ isual inspection of the leaker rod revealed a pinhole leak at one location and about $10 \mathrm{~cm}$ (4 in.) of cladding missing (a "portion" of several pellets was visible) at another location (Refs. 15 and 16). Slight swelling and discoloration were also found on an adjacent fuel rod in another assembly. Iodine-131 and -133 levels in the reactor coolant were found to be normal. Only insignificant amounts of fuel were dispersed from the fuel rod. The initiating cause (or primary failure mechanism) of this cladding defect has not been identified. The associated fuel assembly was in the reactor core during the first three cycles of reactor operation. A review and evaluation of the coolant radiochemistry behavior for the Rancho Seco Unit shows that the initial cladding breach did not occur during the third cycle of operation, but most likely occurred during the first cycle. Deterioration of the defect area has erased all physical traces of the primary failure mechanism. With only one fuel rod 
within the batch identified as a leaker, it is apparent that the initial cladding defect was a random, low probability event which is not attributable to a systematic type of failure mechanism. B\&w projects that this was an isolated hydriding failure due to random contamination. A careful study of this failure is being made by the licensee, and a copy of the report has been requested by the NRC.

During 1980, a total of 20 broken hold-down springs (see Section 3.2.3) were found at Crystal River-3, Davis Besse-1, and 0conee-1 and iodine spiking (see Section 3.2.4) occurred at Crystal River-3 and Davis Besse-1.

Information is available on the B\&W fuel surveillance programs shown in Table 2. The B\&W/Duke (a) $15 \times 15$ Fuel Surveillance Program in Oconee-1 was completed in 1979 and is described in References 17-19. The DOE (b)/ Duke/AP\&L (b)/B\&W Extended Burnup Programs involve irradiations in Oconee-1 and Arkansas-1. (c) Recent results from and plans for the DOE/Duke/B\&W extended Burnup Program are presented in Refences 20-22; other reports issued from the program are References 23-27. Recent information on the DOE/AP\&L/B\&W Extended Burnup Program is in Reference 28; other reports published under the program are References 29-32. The OOE/SMUD ${ }^{(\mathrm{d}) / B \& W}$ Axial Blanket Fuel Design and Development Program in Rancho Seco is described in References 33 and 34. Information on the EPRI/Duke/B\&W Cooperative Program on PWR fuel rod performance in 0conee-2 is contained in References 35-42. The B\&W/Duke Fuel Rod Bow Program in Oconee-2 is described in Reference 43. The B\&W/Duke Low Absorption Grid Program in 0conee-2 is discussed in References 44 and 45 . Reference 46 provides information on the B\&W/Duke $17 \times 17$ Lead Test Assembly (LTA) Demonstration Program in Oconee-2.

\subsubsection{Combustion Engineering, Inc. (C-E)}

As shown in Table 5, Combustion Engineering fuel was irradiated in all eight of their reactors during 1980 (Ref. 47). Six of the reactors use a

\footnotetext{
(a) Duke Power Company (Duke).

(b) U.S. Department of Energy (DOE); Arkansas Power \& Light Company (AP\&L).

(c) Arkansas Nuclear One-Unit 1 (Arkansas-1).

(d) Sacremento Municipal Utility District (SMUD).
} 


\section{TABLE 5. Summary of Combustion Engineering Fuel Irradiated and/or Discharged}

\begin{tabular}{|c|c|c|c|c|c|c|c|}
\hline $\begin{array}{c}\text { Reactor } \\
\text { (fuel cycles) }\end{array}$ & $\begin{array}{r}\text { Fuel } \\
\text { Batch } \\
\end{array}$ & $\frac{\text { No. of }}{\text { Irradiated }}$ & $\frac{\text { ssemblies }}{\text { Discharged }}$ & $\frac{\text { No. of } F}{\text { Irradiated }}$ & $\frac{\text { Le } 1 \text { Rods }}{\text { Discharged }}$ & $\frac{\text { Batch-Averaged } B}{\text { as of Dec. } 1980}$ & $\frac{\text { rnup, Mud }}{\text { at Discharge }}$ \\
\hline $\begin{array}{l}\text { Calvert } C 1 \text { iffs }-1 \\
\text { (Cycles } 4 \text { and } 5 \text { ) }\end{array}$ & $\begin{array}{l}B \\
D \\
E \\
F \\
G\end{array}$ & $\begin{array}{r}1 \\
72 \\
72 \\
72 \\
92\end{array}$ & $\begin{array}{l}1 \\
71 \\
20 \\
--- \\
--\end{array}$ & $\begin{array}{r}162 \\
12,672 \\
12,672 \\
12,672 \\
16,192\end{array}$ & $\begin{array}{r}162 \\
12,496 \\
3,520 \\
--- \\
--\end{array}$ & $\begin{array}{r}32,300 \\
21,200 \\
11,300 \\
<100\end{array}$ & $\begin{array}{c}43,000 \\
30,500 \\
21,900 \\
\ldots- \\
-\end{array}$ \\
\hline $\begin{array}{l}\text { Calvert cliffs }-2 \\
\text { (Cycle 3) }\end{array}$ & $\begin{array}{l}B \\
C \\
D \\
E\end{array}$ & $\begin{array}{l}1 \\
68 \\
84 \\
64\end{array}$ & $\begin{array}{l}--- \\
--- \\
---\end{array}$ & $\begin{array}{r}164 \\
11,632 \\
14,784 \\
11,264\end{array}$ & $\begin{array}{l}--- \\
--- \\
--- \\
--\end{array}$ & $\begin{array}{l}34,200 \\
33,900 \\
22,000 \\
10,300\end{array}$ & $\begin{array}{l}-- \\
\cdots- \\
---\end{array}$ \\
\hline $\begin{array}{l}\text { Fort Calhoun } \\
\text { (Cycles } 5 \text { and } 6)\end{array}$ & $\begin{array}{l}D_{0} \\
D_{1} \\
E_{6} \\
E_{1} \\
F_{0} \\
F_{1} \\
G\end{array}$ & $\begin{array}{r}17 \\
4 \\
16 \\
16 \\
20 \\
16 \\
44\end{array}$ & $\begin{array}{l}16 \\
4 \\
16 \\
16 \\
\cdots \\
--- \\
---\end{array}$ & $\begin{array}{r}2,992 \\
704 \\
2,816 \\
2,816 \\
3,520 \\
2,816 \\
7,744\end{array}$ & $\begin{array}{r}?, 816 \\
704 \\
2,816 \\
?, 816 \\
--- \\
--- \\
---\end{array}$ & $\begin{array}{c}40,300 \\
-- \\
29,100 \\
-- \\
25,100 \\
24,900 \\
15,000\end{array}$ & $\begin{array}{c}33,400 \\
30,200 \\
25,000 \\
27,800 \\
\cdots \\
-- \\
=-\end{array}$ \\
\hline $\begin{array}{l}\text { Maine Yankee } \\
\text { (Cycles } 4 \text { and } 5)\end{array}$ & $\begin{array}{l}\mathrm{E}_{16} \\
\mathrm{~F}_{0} \\
\mathrm{G}_{0} \\
\mathrm{G}_{41} \\
\mathrm{G}_{42} \\
\mathrm{H}_{0} \\
\mathrm{I}_{0} \\
\mathrm{I}_{4}\end{array}$ & $\begin{array}{r}61 \\
12 \\
16 \\
4 \\
12 \\
40 \\
48 \\
24\end{array}$ & $\begin{array}{l}60 \\
12 \\
--- \\
--- \\
--- \\
--- \\
---\end{array}$ & $\begin{array}{r}9,760 \\
1,968 \\
2,816 \\
688 \\
2,064 \\
7,040 \\
8,448 \\
4,128\end{array}$ & $\begin{array}{c}9,600 \\
?, 968 \\
--- \\
--- \\
--- \\
-- \\
--\end{array}$ & $\begin{array}{c}23,900 \\
-- \\
28,200 \\
29,400 \\
29,700 \\
27,200 \\
16,000 \\
19,000\end{array}$ & $\begin{array}{c}29,700 \\
33,200 \\
--- \\
--- \\
-- \\
-- \\
-- \\
--\end{array}$ \\
\hline $\begin{array}{l}\text { Millstone-2 } \\
\text { (Cycles } 3 \text { and } 4 \text { ) }\end{array}$ & $\begin{array}{l}B \\
C \\
D \\
E\end{array}$ & $\begin{array}{r}6 \\
68 \\
72 \\
72\end{array}$ & $\begin{array}{c}5 \\
68 \\
-- \\
\cdots\end{array}$ & $\begin{array}{r}984 \\
11,632 \\
12,672 \\
12,672\end{array}$ & $\begin{array}{c}820 \\
1 ., 632 \\
\ldots \\
-.-\end{array}$ & $\begin{array}{c}18,500 \\
--- \\
21,500 \\
12,000\end{array}$ & $\begin{array}{c}33,800 \\
31,300 \\
--- \\
--\end{array}$ \\
\hline $\begin{array}{l}\text { Palisades } \\
\text { (Cycle 4) }\end{array}$ & 0 & 60 & $\ldots$ & 12,960 & --- & 24,900 & -+ \\
\hline $\begin{array}{l}\text { St. Lucie-1 } \\
\text { (Cycles } 3 \text { and } 4 \text { ) }\end{array}$ & $\begin{array}{l}B \\
C_{0} \\
C_{1} \\
C_{2} \\
D_{0} \\
D_{1} \\
E_{1} \\
E_{6} \\
F_{1} \\
F_{6}\end{array}$ & $\begin{array}{l}21 \\
40 \\
12 \\
16 \\
40 \\
20 \\
28 \\
40 \\
48 \\
40\end{array}$ & $\begin{array}{l}21 \\
39 \\
12 \\
16 \\
--- \\
--- \\
--- \\
--- \\
---\end{array}$ & $\begin{array}{l}3,444 \\
7,040 \\
1,968 \\
2,624 \\
7,040 \\
3,520 \\
4,928 \\
7,040 \\
8,448 \\
7,040\end{array}$ & $\begin{array}{c}3,444 \\
5,864 \\
1,968 \\
2,624 \\
--- \\
--- \\
--- \\
-- \\
-- \\
--\end{array}$ & $\begin{array}{c}-- \\
29,200 \\
\cdots \\
22,100 \\
23,100 \\
15,300 \\
12,100 \\
6,300 \\
4,700\end{array}$ & $\begin{array}{c}28,300 \\
25,400 \\
29,000 \\
30,000 \\
-. \\
-- \\
-- \\
-- \\
-- \\
---\end{array}$ \\
\hline $\begin{array}{l}\text { Arkansas-2(a) } \\
\text { (Cycle 1) }\end{array}$ & $\begin{array}{l}A \\
B \\
C\end{array}$ & $\begin{array}{l}61 \\
60 \\
56\end{array}$ & $\begin{array}{l}--- \\
--\end{array}$ & $\begin{array}{l}14,396 \\
13,440 \\
12,808\end{array}$ & --- & $\begin{array}{r}10,100 \\
9,700 \\
7,000\end{array}$ & -- \\
\hline
\end{tabular}

(a) Arkansas Nuclear One-Unit 2. 
$14 \times 14$ fuel assembly design; Palisades uses a $15 \times 15$ design; Arkansas-2 (a) uses a new $16 \times 16$ design that is the precursor to Combustion Enginering's standardized System $80^{(B)}$ design. Information on the performance of $\mathrm{C}-\mathrm{E}$ fuel is provided in References 48-51. C-E fuel surveiliance programs are listed in Table 2. Reference 52 provides information on the EPRI/C-E surveillance programs. The status of burnup experience, as of December 31, 1980, with C-E, all-Zircaloy assemblies is presented in Table 6. A tota 1,802 assemblies or a total of 315,141 fuel rods have been discharged. There were 1,271 active fuel assemblies, which contained a total of 235,052 fuel rods.

Table 7 shows the typical equilibrium iodine-131 concentrations in the primary coolants of $\mathrm{C}-\mathrm{E}$ reactors during 1980. For this report, C-E indicated they were not going to convert the iodine concentrations to estimated numbers of failed fuel rods because of the uncertainties involved (e.g., radionuclide escape rate models are so variable). (b) During 1980, iodine spiking (see Section 3.2.4) occurred at Arkansas-1 and St. Lucie-1. The latter had an extended period of power operation during 1980 with a nominal level of fuel leakage (Ref. 53). On January 15, 1981, low level cladding failure was noted at Palisades (Ref. 54), which contained fuel supplied by Combustion Engineering, Inc., and by Exxon Nuclear Company (see Section 2.2.3). Minor fuel cladding degradation was known to exist at Maine Yankee in 1979 and 1980 (Refs. 55-57) and the cause of those fuel failures (15 to 25 fuel rods are believed to have failed) is discussed in Section 3.1.3.1.

\subsubsection{Exxon Nuclear Company, Inc. (ENC)}

Exxon Nuclear continues to be the sole domestic supplier of both BWR and PWR fuel. Because it is not a power plant vendor, ENC provides reload fuel. Although their reload fuel designs are basically similar to those of the fuel being replaced, ENC performs its own design analysis, and their fuel has its

(a) Arkansas Nuc lear One-Unit 2 (Arkansas-2). System $80^{\circledR}$ is a registered trademark of Combustion Engineering, Inc.

(b) In the previous annual report (Ref. 2), it was indicated that $\mathrm{C}-\mathrm{E}$ estimated, based on the Tevel of iodine-131 in the reactor coolant (data in Ref. 48), that 18 rods out of 225,000 (corresponds to a defect rate of less than 0.01\%) had failed as of February 1, 1979. 
TABLE 6. Combustion Engineering 8urnup Experience with A1\}-Zircaloy-Assemblies: Status as of December 31,1980

Active

Fuel Assemblies with

Pressurized Fuel Rods

Fuel Assembly 8atch-Averaged Burnup, MWd/MTU

$$
0 \text { to } 3,900
$$

4,000 to 7,900

8,000 to 11,900

12,000 to 15,900

16,000 to 19,900

20,000 to 23,900

24,000 to 27,900

28,000 to 31,900

32,000 to 35,900

36,000 to 39,900

40,000 to 43,900

Totals

No. of Fuel No. of

Assemblies Fuel Rods

\begin{tabular}{rrrr}
92 & & 16,192 \\
144 & & 28,296 \\
305 & & 60,220 \\
184 & & 32,384 \\
72 & & 12,576 \\
222 & & 39,044 \\
136 & & 26,336 \\
46 & & 8,032 \\
69 & & 11,796 \\
0 & & 0 \\
1 & & 176 \\
\hline 1,271 & 235,052
\end{tabular}

Discharged

$\frac{\text { Pressurized Fuel Rods }}{\text { No. of FueT No. of }}$

Assemblies

Assemblies

Fuel Rods

$\frac{\operatorname{Rods}}{0}$

1,048

3,696

27,632

43,452

28,884

62,752

61,516

6,308

37

0

$\frac{1}{1,380}$

$\frac{162}{235,450}$
Discharged Fuel Assemblies with NonPressurized Fuel Rods $\frac{\text { Assemblies Fuel Rods }}{0}$

0

0

208

190

24

0

0

0

0
0

0

40,500

35,351

3,840

0

0

0

0

$\begin{array}{r}0 \\ 0 \\ \hline 422\end{array}$

$\begin{array}{r}0 \\ 0 \\ \hline 79,591\end{array}$


TABLE 7. Typical Equilibrium Iodine-131 Concentrations in the Primary Coolant of Combustion Engineering Reactors During 1980

\begin{tabular}{|c|c|c|c|c|c|c|}
\hline & Reactor & Fuel & Beginning & End & 1980 Equi & $\frac{\text { um Conditions }}{\text { Iodine-131, } \mu \mathrm{Ci} / \mathrm{g}}$ \\
\hline & - Kedctor & & of Cycle & of lycle & Power, 10 & lodine- $-131, \mu \mathrm{L} / \mathrm{g} / \mathrm{g}$ \\
\hline & Calvert Cliffs-1 & 4 & $07 / 10 / 79$ & $10 / 17 / 80$ & 100 & 0.004 to 0.009 \\
\hline & & 5 & $12 / 21 / 80$ & $04 / 82^{(a)}$ & $\mathrm{NA}{ }^{(b)}$ & $\mathrm{NA}^{(\mathrm{b})}$ \\
\hline & Calvert Cliffs -2 & 3 & $12 / 06 / 79$ & $01 / 17 / 81$ & 100 & 0.003 to 0.008 \\
\hline & Fort Calhoun & 5 & $12 / 15 / 78$ & $01 / 18 / 80$ & 98 & 0.02 \\
\hline & & 6 & $06 / 08 / 80$ & $09 / 81^{(a)}$ & 100 & 0.03 to 0.06 \\
\hline & Maine Yankee & 4 & $08 / 25 / 78$ & $01 / 11 / 80$ & 62 (100 est) & 0.03 ( 0.15 est) \\
\hline & & 5 & $03 / 09 / 80$ & $05 / 08 / 81$ & 100 & 0.003 to 0.005 \\
\hline 它 & Millstone-2 & 3 & $05 / 18 / 79$ & $08 / 16 / 80$ & 100 & 0.003 to 0.006 \\
\hline & & 4 & $10 / 20 / 80$ & $01 / 82^{(a)}$ & 100 & 0.006 \\
\hline & Palisades & 4 & $05 / 24 / 80$ & $08 / 81^{(a)}$ & 100 & 0.04 to $0.1^{(c)}$ \\
\hline & St. Lucie-1 & 3 & $06 / 08 / 79$ & $03 / 15 / 80$ & 100 & 0.01 \\
\hline & & 4 & $05 / 07 / 80$ & $10 / 81^{(a)}$ & 100 & 0.02 to 0.06 \\
\hline & Arkansas-2 ${ }^{(d)}$ & 1 & $12 / 06 / 78$ & $03 / 28 / 81$ & 100 & 0.10 to 0.15 \\
\hline
\end{tabular}

(a) Target end-of-cycle date.

(b) Not available (NA).

(c) Predominately non-C-E supplied fuel.

(d) Arkansas Nuclear One-Unit 2. 
Own unique design features. For example, ENC cladding is slightly thicker than others (see Table 1), and ali ENC fuel assemblies are reconstitutable. (a)

Performance of ENC fuel is summarized in Reference 58 . Table 8 provides a summary of ENC fuel exposure in 1980 (Ref. 59). There were 2445 fuel assemblies in domestic and foreign reactor cores (1338 in BWRs and 1107 in 8 WRs) as of December 31, 1980. During 1980, a tota 1 of 494 fuel assemblies were discharged from domestic and foreign reactors (374 from BWRs and 120 from PWRs). According to ENC, there were no failures of ENC fuel in 1980. In October 1981, ENC indicated that there was no further word yet regarding the $P_{a}$ lisades fuel (see Section 2.2.2), which was being examined at that time.

ENC fuel surveillance programs are shown in Table 2. Reference 44 provides information on the EPRI/ENC programs.

\subsubsection{General Electric Company (GE)}

Table 9 provides a summary of Genera? Electric's BWR/2-5 experience with $8 \times 8$ fuel as of January 198I, which shows that less than $0.02 \%$ of the $1,239,000$ fuel rods $(b)$ in operating and discharged $8 \times 8$ fuel bundles are est $i$ mated to have failed (Ref. 60). (c) Currently, over $93 \%$ of all GE fuel operating in commercial reactors is of the $8 \times 8$ fuel bandle design.

(a) The on $7 y$ B\&W fuel assemblies that are designed to be reconstitutable and that were in reactors in 1980 are the two Mark CR $(17 \times 17)$ LTAs in Oconee-2. All of the $C-E$ fuel assemblies under irradiation in 1980 were reconstitutable, except for one Batch-C fuel assembly in Cycle 4 at St. Lucie-1. All GE fuel bundles are reconstitutable. Westinghouse with commence delivery of fuel assemblies with reconstitutable design features in the first quarter of 1982.

(b) As of January 1, 1980, the cumulative number of fue 1 rods loaded (in $8 \times 8,8 \times 8 R$, and prepressurized $8 \times 8 R$ type fue 1 bundles) into 8WRs was $1,026,414$ (Ref. 2).

(c) In the previous annual report (Ref. 2), the GE estimates for rod failure rates for $7 \times 7,7 \times 7 R, 8 \times 8$, and $8 \times 8 R$ plus $8 \times 8 R$ (prepressurized) fuel types as of January 1, 1980 were $1.01 \%, 0.066 \%, 0.16 \%$, and $0.002 \%$, respectively. In May 1979, it was reported by GE (Ref. 6I) that the estimated rod failure rates for $7 \times 7,7 \times 7 R, 8 \times 8$, and $8 \times 8 R$ fuel types were $0.98 \%, 0.043 \%, 0.028 \%$, and $0 \%$. 
TABLE 8. Summary of Exxon Nuc lear Fuel Exposure in $1980(a)$

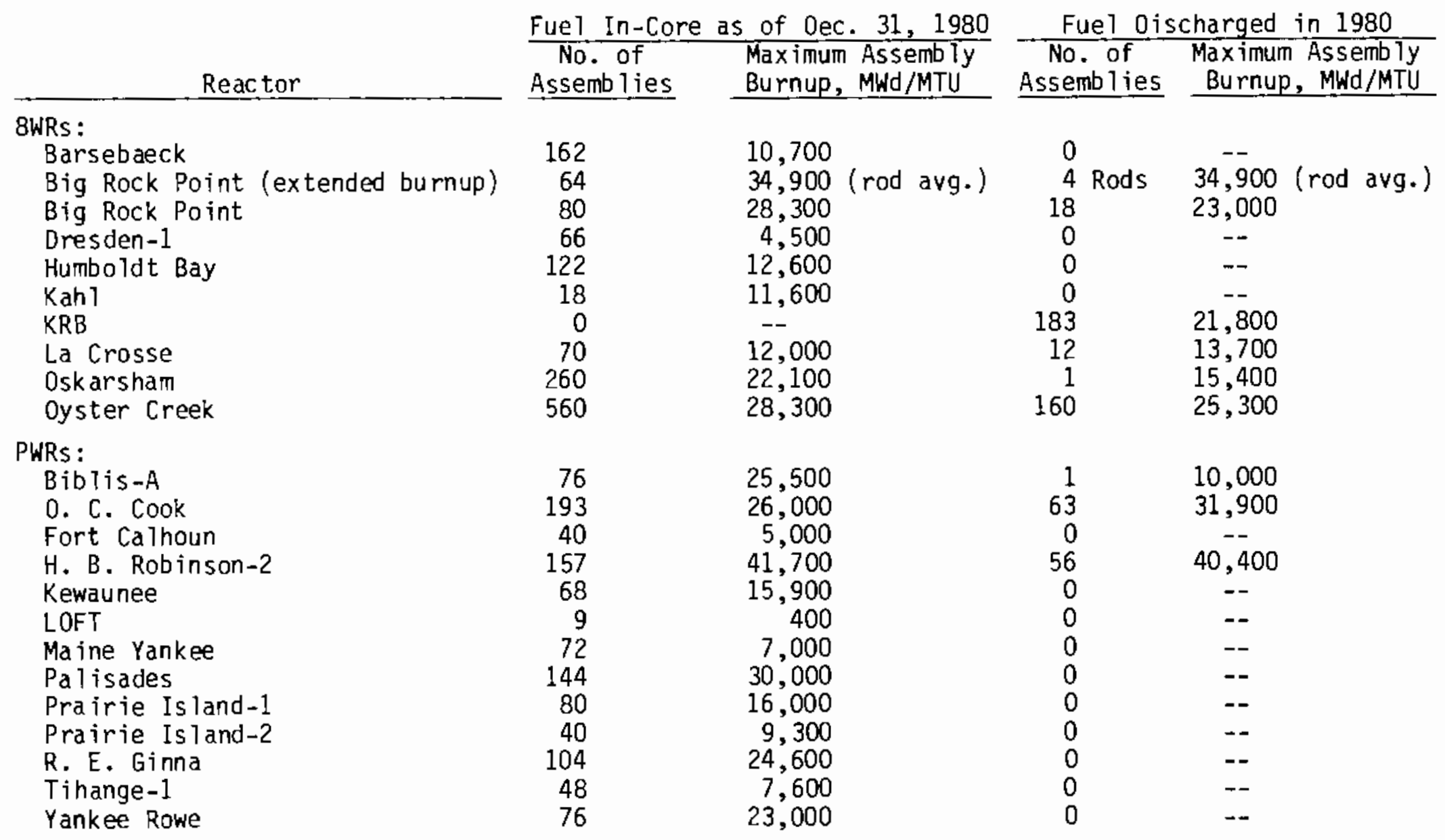

(a) There were no failures of Exxon Nuctear in 1980. 
TABLE 9. General ETectric BWR/2-5 Fue1 Experience Summary (January 1981)

$$
\begin{aligned}
& \text { Total rods in core or discharged } \frac{\text { A } 118 \times 8}{1,239,000^{(a)}} \\
& \text { Estimated sound rods, \% } 99.98 \\
& \text { Lead assembly exposure, MNd/MTU } \quad 40,000 \\
& \text { Peak linear heat generation rate, } \\
& \mathrm{kW} / \mathrm{m}(\mathrm{kW} / \mathrm{ft}) \quad 44.0(13.4)
\end{aligned}
$$

(a) Cumutative

The overall faiture rate for fuel rods irradiated in 1980 was less than $0.01 \%$. GE stated that they were unable to supply an estimate of the percent of failed rods during calendar year 1980 for each plant because invidual licensees own the fuel.

Experience with GE BWR fue? through January 1981 is summarized in Reference 60. Information on GE fuel performance is also described in Reference 61.

As of January 1981, more than 2,038,000 GE production fuel rods are now in or have completed operation in 41 commercial BWRs in the U.S. and abroad. In addition, over 950 developmental irradiations have been completed or are underway.

It was reported in 1980 that the failure of 75 rods at Vermont Yankee was associated with a metallic incursion in the feedwater (see Section 3.1.3.2). Some gadolinia fuel rods (the NRC estimates less than 100) were found to be underpressurized (see Section 3.2.2). Iodine spiking occurred in 1980 at Brunswick-2 (see Section 3.2.4).

GE depends on results from fission product monitoring, fuel sipping, and site inspections, as well as detailed fuel inspections and postirradiation examinations, to develop its data base on BWR fuel.

GE, as well as other fuel vendors, uses lead test assemblies to confirm design adequacy or to provide early warning of negative design features. A summary of current surveillance programs with GE lead test assembly and extended burnup bundles is given in Table 10 and also in Table 2 . Reference 52 provides information on the EPRI/GE programs. 
TABLE 10. Sumary of General Electric Lead Test Assembly and Extended Burnup Bundles

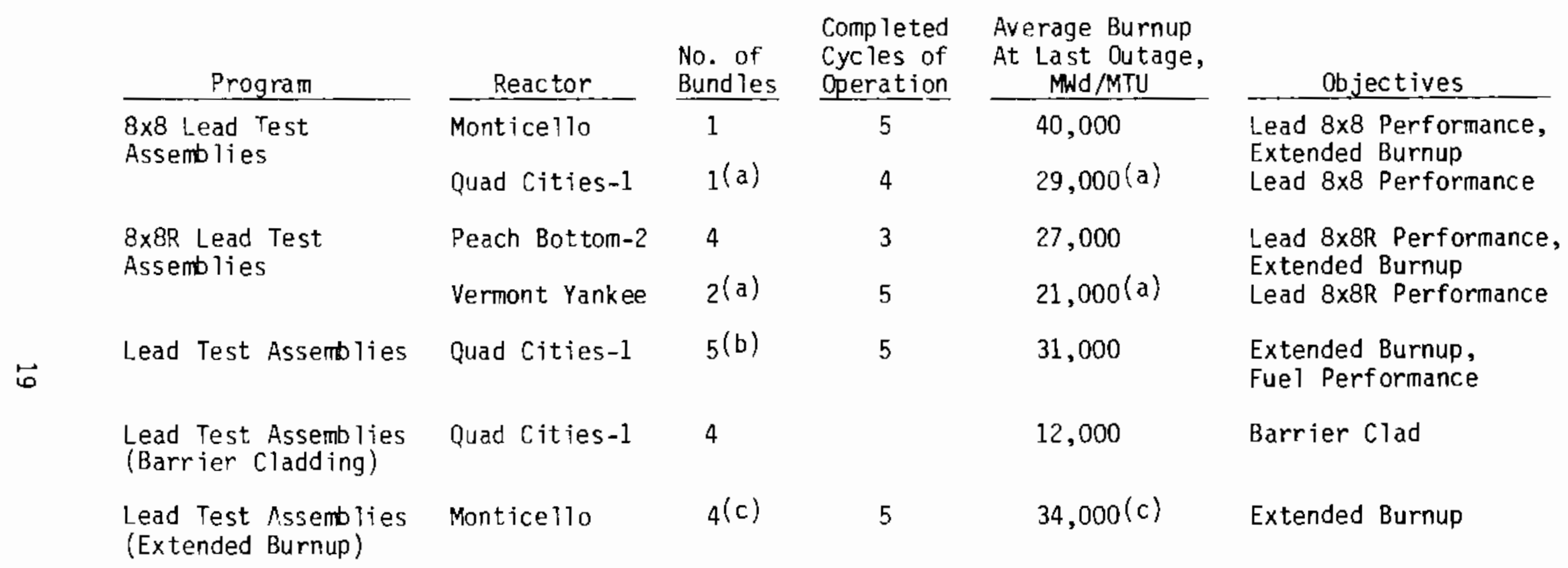

\footnotetext{
(a) Bund le(s) now discharged.

(b) Three bund les now discharged.

(c) One bund le discharged. The remaining three bundles include the $8 \times 8$ lead test assembly.
} 


\subsubsection{Westinghouse Electric Corporation (W)}

Westinghouse issues an annual report describing the operating experience of their fuel in domestic and foreign reactors. Reference 62 provides the detailed information on Westinghouse fuel experience up to December $31,1980$. A total of 901,700 Zircaloy-clad fuel rods are currently operating in 35 commercial PWRs in the U.S. and abroad. Those rods plus previously discharged fue 1 brings the total number of Westinghouse Zircaloy-clad fuel rods to $1,996,400$. Table 11 presents a burnup summary for the fuel rods discharged and being irradiated through 1980. (a) Average burnup for the discharged fuel is 24,500 MWd/MTU and average burnup for all fuel is 20,600 MWd/MTU (this burnup is lower because fresh, unburned fuel is included in that number).

Table 12 provides a Westinghouse fuel performance summary on a plant-byplant basis. The data on peak burnup in Table 12 reflect an average of the high burnup fuel assemblies (batch) in a region. The values for percent of design basis activity release rates for Jose' Cabrera, Indian Point-2, and $\mathrm{Ko}-\mathrm{Ri}$ in Table 12 are higher than the values for the other plants but Westinghouse indicates that they are still considerably less than the Technical Specification limit.

Baffle jetting resulted in the failure of two fue 1 rods in 1980 (see Section 3.1.1). Grid strap damage was observed on 89 fuel assemblies in 1980 (see Section 3.1.2). Cracking of control rod guide tube support pins was found in 1980 at a foreign PWR (see Section 3.2.1). During 1980, 40 cracked or broken hold-down springs were noted at two foreign PWRs (see Section 3.2.3).

Westinghouse fuel surveillance programs are shown in Table 2. For individual discharged fuel assemblies, the highest burnups have been in the range of 39,000 to 46,500 MWd/MTU. As part of the EPRI/W high burnup program, four high burnup demonstration assemb)ies have been irradiated in Zion-2 (Cycle 4 core) to a burnup of $46,500 \mathrm{MWd} / \mathrm{MTU}$. The burnups of these four assemblies will be extended to about 55,000 Mid/MTU in the Cycle 6 core (starts in early

(a) Table 11 does not include 3043 fuel rods in 17 fuel assemblies (14 $\times 14$ type) at Ginna. Westinghouse indicated in September 1981 that those rods were illadvertaric iy left out of Table 11 when it was transmitted to the NRC. 
TABLE 11. Westinghouse Zircaloy-Clad Fuel Burnup Status as of December 31, 1980: Assemblywise Burnup Distribution of Fuel Rods

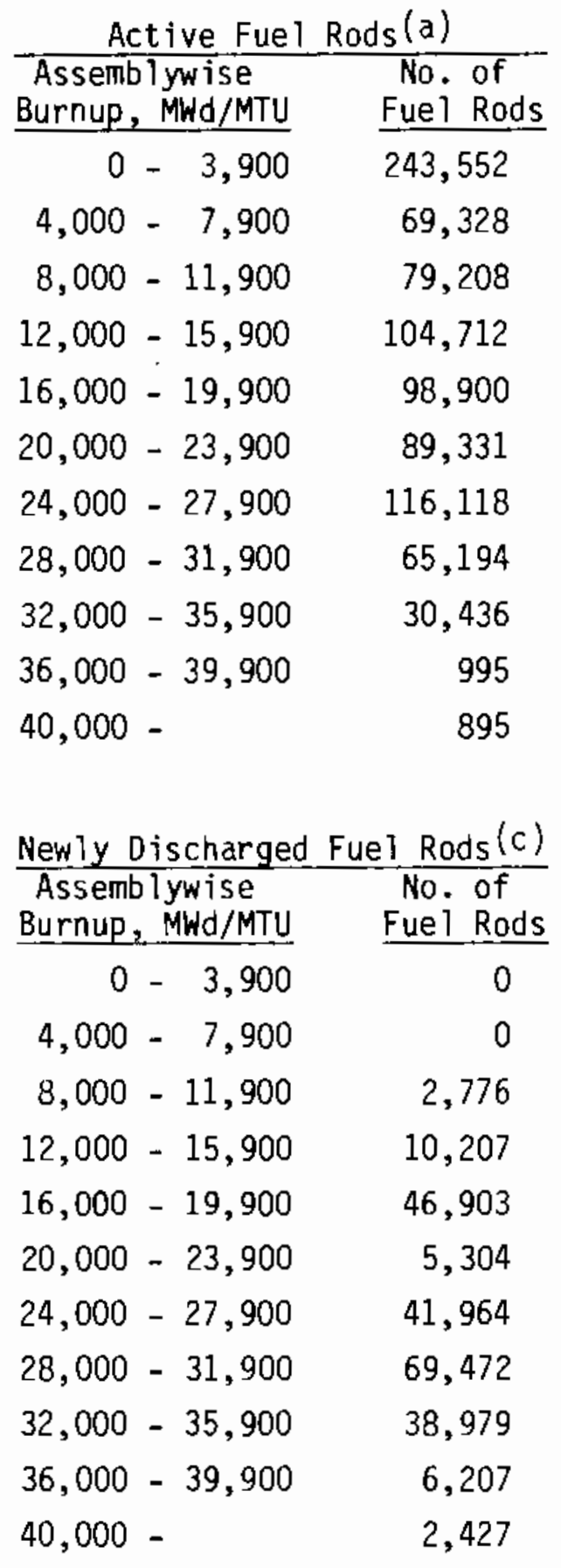

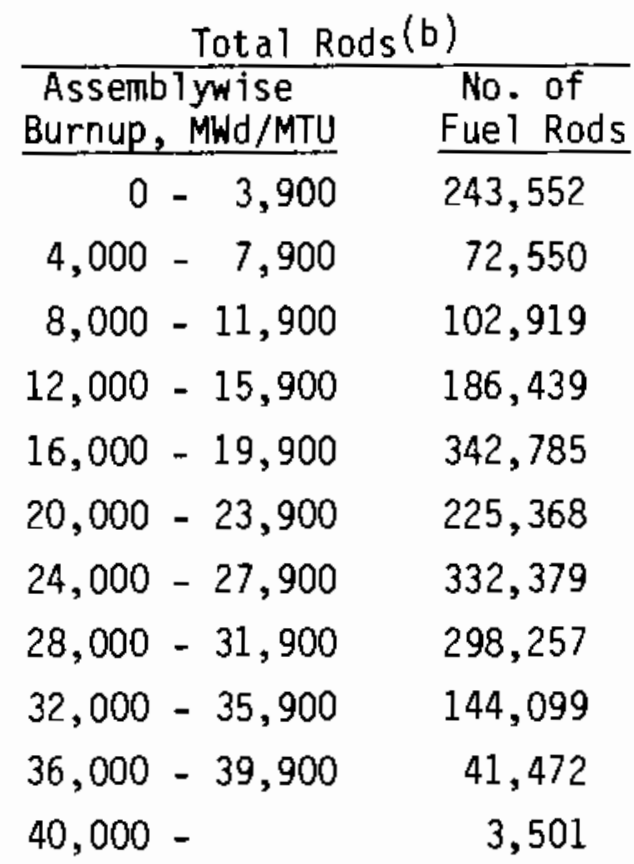

$\frac{\text { Total 0ischarged Fuel Rods (d) }}{\text { Assemblywise }}$ Burnup, MWd/MTU Fuel Rods$$
0-3,900
$$$$
4,000-7,900 \quad 3,222
$$$$
8,000-11,900 \quad 23,711
$$$$
12,000-15,900 \quad 81,727
$$$$
16,000-19,900 \quad 243,885
$$$$
20,000-23,900 \quad 136,037
$$$$
24,000-27,900 \quad 216,261
$$$$
28,000-31,900 \quad 233,063
$$$$
32,000-35,900 \quad 113,663
$$$$
36,000-39,900 \quad 40,477
$$$$
40,000-\quad 2,606
$$

\footnotetext{
(a) Fuel rods not discharged from operating plants.

(b) Active fuel rods plus total number of discharged fuel rods.

(c) Fuel rods discharged during calendar year 1980.

(d) Fuel rods discharged from 1969 through December 1980.
} 


\section{TABLE 12. Westinghouse Fuel Performance Status Report (fourth quarter 1980)}

\begin{tabular}{|c|c|c|c|c|}
\hline Reactor & Location & $\begin{array}{c}\text { Current } \\
\text { Cycle No. }\end{array}$ & $\begin{array}{c}\text { Peak Batch Average } \\
\text { Burnup as of Dec. } 31 \text {, } \\
1980, \text { (MWd/MTU) }\end{array}$ & $\begin{array}{l}\text { Percent of Design } \\
\text { Basis Activity } \\
\text { Release Rate(a) } \\
\end{array}$ \\
\hline Jose' Cabrera & Spain & 10 & 31,400 & 2.8 \\
\hline Beznau-1 & Switzerland & 10 & 33,500 & 0.75 \\
\hline Mihama-1 & Japan & 2 & 18,500 & (b) \\
\hline Point Beach-1 & U.S. & 9 & 34,500 & 1.9 \\
\hline Mihama-2 & Japan & 4 & 29,600 & (b) \\
\hline Point Beach-2 & U.S. & 7 & 36,100 & 0.04 \\
\hline Surry-1 & U.S. & 5 & 24,000 & (c) \\
\hline Turkey Point-3 & U.S. & 7 & 33,000 & (b) \\
\hline Surry-2 & U.S. & 4 & 32,100 & 0.08 \\
\hline Zion-1 & U.S. & 5 & 36,100 & 0.63 \\
\hline Ind ian Point-2 & U.S. & 5 & 34,100 & 2.9 \\
\hline Turkey Point-4 & U.S. & 7 & 33,200 & (b) \\
\hline Prairie Island -1 & U.S. & 6 & 34,900 & $\leq 0.01$ \\
\hline Zion-2 & U.S. & 5 & 37,100 & 0.14 \\
\hline Kewaunee & U.S. & 6 & 31,900 & $\leq 0.01$ \\
\hline Prairie Is 1 and- 2 & U.S. & 5 & 35,100 & 0.02 \\
\hline Trojan & U.S. & 3 & 28,300 & 0.26 \\
\hline Indian Point-3 & U.S. & 3 & 30,500 & (d) \\
\hline Beaver Valley & U.S. & 2 & 19,300 & (e) \\
\hline Sa Tem-1 & U.S & 3 & 26,900 & (d) \\
\hline Ko-Ri & Korea & 2 & 25,900 & 4.2 \\
\hline Farley-1 & U.S. & 3 & 27,300 & 0.02 \\
\hline Ohi-1 & Japan & 2 & 16,900 & (b) \\
\hline 0. C. Cook-2 & U.S. & 3 & 28,700 & 0.33 \\
\hline North Anna-1 & U.S. & 3 & 26,600 & 0.24 \\
\hline Ohj-2 & Japan & 2 & $\leq 2,000$ & (b) \\
\hline North Anna-2 & U.S. & 1 & $<1,000$ & (e) \\
\hline Sequoyah-1 & U.S. & 1 & $<1,000$ & (e) \\
\hline Ringhals-3 & Sweden & 1 & $<1,000$ & (e) \\
\hline Salem-2 & $U$. & 1 & $<1,000$ & (b) \\
\hline
\end{tabular}

(a) Activity release rate calculated from coolant activity averaged over the quarter and presented as percent of that iodine-131 release rate which establishes the basis for design of plant shielding and coolant cleanup system equipment.

(b) No data reported.

(c) Maintenance and inspection or repair during period of report.

(d) Plant refueling during period of report.

(e) Reported information reflects last period of operation or inferrence from short periods of operation during period of report. 
1981) of Zion-1. Reference 52 provides information on the EPRI/W program. References 63 and 64 describe the evaluation of the significant amount of data from Westinghouse high burnup fuel experience.

Region average burnups to 29,000 MWd/MTU have been achieved by $17 \times 17$ fuel assemblies, which are being irradiated in five plants. Four demonstration $17 \times 17$ Optimized Fuel Assemblies completed their first cycle of operation in the fall of 1980 .

As shown in Table 12, Westinghouse continues the practice of evaluating fuel performance in terms of coolant activity leve1. (a) coolant design basis activity varies somewhat from plant to plant (e.g., because of reactor power and coolant purification rate). However, for comparison purposes, approximately $2 \mu \mathrm{Ci}$ of iodine-131 per gram of coolant water is equivalent to $100 \%$ of the coolant design basis. Westinghouse states that the number of defected fuel rods cannot be directly inferred from the coolant radioactivity level. The "coolant activity design basis" is equivalent to the predicted reactor coolant activity concentration, at rated operating power and normal operation of the reactor coolant letdown and cleanup system, resulting from a fue 1 defect level of one percent at an assumed escape rate coefficient of radioiodine of $1.3 \times 10^{-8} \mathrm{sec}^{-1}$. The term "defect level" is defined as the equivalent percentage of defective average power density fuel rods expressed as a percentage of reactor rated power contributing radioactivity to the coolant at a specific escape rate through cladding defects. For example, a reactor operating at full power of $3000 \mathrm{MW}$ (thermal) having defective fuel rods generating $30 \mathrm{MW}$ (therma 1) would be operating at a fuel defect level of $1 \%$, with a resulting steady-state iodine-131 coolant activity of approximately $2 \mu \mathrm{Ci} / \mathrm{g}$ of coolant water. There is no "standard defect," and the actual release rates from different types of cladding defects can vary significantly. Thus, the actual number of fuel rods that may be defected cannot be defined based on coolant activity. The reported coolant activity levels (Table 12), combined with the burnup experience (Table 11), indicate the

(a) In the previous annual report (Ref. 2) it was ind icated by westinghouse that iodine-131 activity levels were reported in 23 plants in 1979. Westinghouse estimated that approximately 100 rods failed (corresponds to a defect rate of approximately $0.017 \%$ ). 
reliability and good performance of Westinghouse Zircaloy-clad fuel. According to Westinghouse, in some cases the coolant activity indicates that a small number of cladding defects is present. Except for two fuel rods in peripheral fuel assemblies that failed due to fretting caused by baffle jetting, no cause has been identified yet for the apparent defects.

\subsubsection{Electric Power Research Institute (EPRI)}

The EPRI LWR Core Materials Performance Program began in mid-1974. A series of program-planning documents was initiated in 1975 . Reference 52 is the fifth such report and discusses progress in the program during 1979 and 1980 and plans for work in 1981 and 1982. The four previous reports included the detailed planning support documents issued in December 1975 (EPRI SR-25) and January 1977 (EPRI NP-370-SR) and the progress reports issued in January 1978 (EPRI NP-737-SR) and February 1979 (EPRI NP-1024-SR).

When the program was initiated, fuel rod problems were emphasized. However, since 1979 additional attention has been focused on other fuel system and core components, especially control rods, burnable poison rods, and fuel channels for BWRs. Four areas are emphasized in the current program: extending fuel burnup beyond the present 30,000 MWd/MTU level, decreasing the capacity factor losses caused by fuel-related restrictions on power maneuvering, extending the life of control rods, and extending the life of BWR fuel channels. The program goal is to increase plant availability. In working toward that goal, effort is underway to: 1) determine the response of core component materials, 2) develop a comprehensive fuel performance data base, and 3) develop accurate models and computer codes.

Presently, the EPRI has 22 active projects. The project scopes range from laboratory studies to large-scale tests of both standard and prototypic fuel assemblies. As noted earlier, the EPRI is extensively involved in fuel surveillance projects that are based on standard product line fuel of the type employed in LWRs at domestic commercial nuclear plants. Data have been co1lected on the detailed performance of fuel assembly components from the cooperative projects between EPRI and each of the five major domestic fuel vendors. In collecting the data under these programs, emphas is was placed on information 
related to current industry concerns (e.g., fission gas release, corrosion, and extended burnup) and also on measured properties of traditional interest (e.g., fuel rod diameter and length, fuel rod spacing, and fuel assembly dimensional changes). To avoid difficulties in shipping and waste disposa1, poolside examinations were emphasized in these cooperative projects. However, limited hot cell examinations were also conducted.

Reference 52 states that "during 1979 and 1980, several projects produced significant results concerning: 1) power reactor fuel performance, particularly fission gas release, fuel swelling, cladding oxidation, fuel rod growth, and fuel rod bow, 2) test reactor fuel performance of new fuel types, particuTarly fission gas release and fuel-cladding mechanical interaction, and 3) fuel rod reliability modeling."

References 65-67 are 1980 directories of technical reports issued by EPRI. Included in the lists of reports in those directories were two (Refs. 68 and 69) from EPRI's Nuclear Division that deal with fuel performance in water-cooled reactors. 



\section{D PROBLEM AREAS OBSERVED DURING 1980}

Over the years, fuel problems have been caused by a number of factors including densification, hydriding, fretting and wear, bowing, and pelletcladding interaction (PCI). NRC staff reports or memoranda have been generated on each item (e.g., Reference 70 on PCI and Reference 71 on guide tube wear). Although several problems that were formerly of concern have been resolved (e.g., fuel densification), some old problems such as baffle jetting, grid strap damage, and crud and corrosion remain, and some new problems have arisen. The following section contains a discussion of 1) problem areas in 1980 that were similar to those in 1979, 2) new problems in 1980, and 3) old problems (1979) that did not reoccur or that were solved.

\subsection{PROBLEMS IN 1980 THAT WERE SIMILAR TO THOSE IN 1979}

\subsubsection{PWR Baffle Jetting}

Baffle jetting was one of the problem areas encountered in 1979. Fuel failure caused by baffle jetting was reported in several plants (Ref. 2). At that time, the vendor, Westinghouse Electric Corporation, recommended that both a visual examination and peening of the joints should be performed to alleviate this problem. The vendor recommended that flat-land peening be used on all outside corner baffle joints and that baffle joints should not be welded together.

During 1980, only one plant, Trojan-1, reported the occurrence of baffle jetting (Refs. 72-76). Two fuel rods (one in each of two fuel assemblies) with cladding damage were observed during a preplanned fuel inspection program. The two assemblies were removed from the core. Failure of the cladding on the PWR fuel rods was caused by water-jet impingement on the fuel rods via an enlarged baffle plate joint gap. The baffle joints were peened by both the knife-edge and flat-land peening methods, as recommended by the vendor.

In May 1980, the licensee for Trojan proposed (Ref. 77) to amend the operating license for the plant to permit installation of two fuel assemblies with a maximum of three rods per assembly with dummy (solid) stainless steel 
rods in the locations that have been subject to cross flow (baffle jetting). The licensee suggested using coolant chemistry as a criterion for surveillance (Ref. 78). Based on 1) review of the information in Reference 77,2 ) required surveillance, and 3) a report of the physics startup tests, the NRC found that the proposed substitution of dummy stainless steel rods was acceptable for Cycle 3 operation (Ref. 79).

The NRC issued a circular in July 1980 about fuel rod damage due to water jetting from baffle plate corners and provided guidelines for recommended actions to all PWR construction permit holders and licensees (Ref. 80). The fuel vendor also performed a sensitivity study of baffle joint gap width to joint jet velocity and established criteria for peening methods. The vendor outlined a baffle joint inspection program and recommended that it should be followed during all refueling operations (until the utility determines that an effective control of baffle jetting has been attained).

As a result of further studies and awareness through vendor and NRC communications, better understanding of the problem was obtained, and the corrective actions appear to have taken effect.

Westinghouse is implementing a design modification at the baffle joints to eliminate this type of failure for plants not yet in operation (Ref. 62).

\subsubsection{Westinghouse Grid Strap Damage}

During 1979, Salem-1, Salem-2, Indian Point-2, and some other PWRs reported grid strap damage on fuel assemblies (Ref. 2). The grid strap damage was caused by corner-to-corner interaction between adjacent fuel assemblies during fuel handling operations. Fuel assemblies that suffered the damage were either removed from the core or disqualified for reloading into the core. The fuel vendor, Westinghouse, recommended additional precautions to correct the problem. The NRC approved the vendor recommendations and issued IE Ciricular No. 80-13 (Ref. 81) on this matter to all licensees for PWRs. That circular required all licensees using Westinghouse $14 \times 14,15 \times 15$, and $17 \times 17$ fuel to visually inspect the grid straps on discharged fuel assemblies and on fuel 
assemblies that are being returned to the core. It also required that the pertinent vendor recommendations on fuel handling precautions be adopted by Iicensees with Westinghouse fuel.

According to an investigation by Westinghouse (Ref. 82), recent refuelings using the revised fuel handling procedures proposed by Westinghouse have revealed no indication of grid damage. In addition, modifications to the grid corners of all newly fabricated fuel are expected to further reduce the probability of grid damage during fuel handing.

In October 1980, two fuel assemblies at Salem-1 were found during the Cycle $2 / 3$ refueling to have damaged grids (Ref. 62). The damage occurred during insertion prior to cycle 2 startup. These assemblies (and previously other fuel assemblies) with damaged grids operated satisfactorily, indicating that some degree of damage may be tolerated without attendant fuel rod defects (Ref. 62).

During the Cycle $4 / 5$ fuel shuffle that started in December 1980, grid strap damage was found in a number of fuel assemblies at Indian Point-2; no damage to fuel rod cladding was identified (Refs. 83 and 84 ). The core was completely discharged and all fuel assemblies were visually inspected, using an underwater TV camera and videotaping system. An updated report (Ref. 85) indicated that 87 of the fuel assemblies were found to have damaged grid straps (19 additional assemblies had trapped debris and were subsequently cleaned). Westinghouse recommended additional fuel assembly handling precautions that minimize the corner interactions between fuel assemblies. There were 49 of these assemblies with damaged grids loaded into the core for cycle 5 . Evaluation of the damage indicated that there will be no adverse effects on the operation in Cycle 5 (Ref. 84).

\section{1 .3 Crud and Corrosion}

\subsubsection{Crud Deposits on PWR Fuel}

Failed fuel assemblies were found at Maine Yankee during the Core 4-5 refueling operation (Ref. 2). Routine inspection (sipping) of all 217 fuel assemblies identified nine assemblies as leakers (Ref. 56). In February 1980, it was indicated that 12 fuel rods (burnups ranged from $\approx 12,000$ to 
22,000 MWd/MTU) had been identified as failed and that hydride blisters had been observed on all failed rods (Ref. B6). At that time the cause of faiture was conjectured to be pellet-cladding interaction (PCI), which was then followed by secondary hydriding (Ref. 86). All the failed rods were prepressurized type fuel rods that contained high-density $\mathrm{UO}_{2}$ pellets--as the NRC noted (Ref. 86), these rods were not of the same vintage as the rods that were involved in the earlier ( 3 to 4 years ago) PCI problems at Maine Yankee.

In March 1980, the licensee transmitted additional information (Ref. 87) to the NRC. The nine fuel assemblies, as well as others, were examined visually with the site periscope. Some of the fuel rods were eddy-current tested; profilometry measurements were made on a small number of rods. The licensee believes that a total of 15 to 25 fuel rods failed, of which 11 were postively identified. The failures of these Batch $H$ fuel rods, which occurred at the end of Cycle 4, were most likely caused by external corrosion associated with crud deposition during the January-March 1979 time period. The licensee does not expect further degradation of the fuel during Cycle 5 . The fuel vendor issued two reports based on their inspection work (Refs. 88 and 89 ).

Five of the nine assemblies were returned to the core for additional irradiation after all fuel rods with through-wall penetrations, as determined by visual and eddy-current examinations, were replaced (solid Zircaloy rods and new fuel rods were employed as replacements). The other four assemblies were discharged. The reactor coolant chemistry results showed a step buildup in activity levels to a higher, relatively stable, value, which suggests, according to the licensee, that the fuel rod failure mechanism was such as to limit failures to a limited number of fuel rods and was not of a core-wide degenerative nature (Refs. 56 and 90).

\subsubsection{Corrosion of BWR Fuel}

In the annual report for 1979 (Ref. 2), it was stated that 75 failed rods ( 71 poison rods, 4 fuel rods) were found in 31 fuel bundles at Vermont Yankee. The failures appeared to be caused by external corrosion. Information submitted by General Electric to the NRC in October 1980 (Ref. 91) indicated that the failures were associated with a metallic incursion in the feedwater. It 
was also stated that this has occurred only once in the BWR operating history and is unlikely to reoccur. Attached to that submittal were the vendor's recommendations (dated September 1979) to BWR plants, which should preclude this type of event in the future.

In 1980, a submittal to the NRC for Vermont Yankee Reload 7 did not indicate how the licensee would address and resolve the previously observed phenomenon of waterside corrosion; as a result the NRC transmitted a number of questions to the licensee (Ref. 92). The NRC observed (Ref. 93) that the licensee's response (Ref. 94) appeared to be at variance (a) with General Electric's conclusions regarding the principal cause and solution for the waterside corrosion (Ref. 91). As a result, the NRC notified the licensee that further discussion of this issue would be required to resolve this apparent divergence of opinion. In response, the licensee stated (Ref. 95) that the failures were "most probably the result of the synergistic effects of variable fuel cladding properties and metallic impurities in the reactor coolant." The major impurity associated with the failures was copper, which appeared to be coming from the copper alloy (admiralty brass) tubing in the main condenser (Ref. 96). Plants without copper-bearing main condenser tubes were thus not expected to experience cladding perforations of this kind.

\subsection{NEW PROBLEMS IN 1980}

\subsubsection{PWR Control Rod Guide Tube Support Pin Cracking}

Support pin inspections at a foreign plant revealed stress-corrosion cracking in Westinghouse-supplied support pins. There have been no previous occurrences. Some support pins are susceptible to stress-corrosion cracking due to the ir low solution heat treatment temperature. The cracked pins were all from one heat treatment lot of material used in foreign reactors. Ouring manufacture, the pins were given a solution heat treatment at temperature below $1255 \mathrm{~K}\left(1800^{\circ} \mathrm{F}\right)$. Testing by the vendor, Westinghouse, shows that a solution

(a) The licensee stated in Reference 94 that the faiTures "were the direct result of an anomalous metallurgical condition..." and that "... an excursion in one or more manufacturing processes" was indicated (as the principal underlying cause of the problem). 
heat treatment at a temperature of at least $1339 \mathrm{~K}\left(1950^{\circ} \mathrm{F}\right)$ results in support pins that are highly resistant to stress-corrosion cracking.

Domestic plants, including Catawba-1 (Ref. 97), North Anna-1 (Ref. 98), Sequoyah-1 (Ref. 99), and Surry-1 (Ref. 100) were notified by Westinghouse regarding the potential for guide tube support pin cracking. This condition (i.e., cracking) appears at Catawba-1 (Ref. 97). The vendor recommended replacing the pins with ones that have been manufactured with a solution heat treatment at a temperature of at least $1366 \mathrm{~K}\left(2000^{\circ} \mathrm{F}\right)$. All pins will be replaced.

The corrective action appears to have solved the problem, because no new incidents were reported in 1980 .

\subsubsection{Underpressurized Gadolinia Fuel Rods}

There are typically four rods containing uraniagadolinia fuel material in an $8 \times 8$ BWR fuel assembly (and as many as eight in more recent designs). A number of such gadolinia fuel rods fabricated between June and October 1980 at General Electric's Wilmington facility did not meet specification requirements on helium fill gas concentration and pressure because of a malfunction in a weld station. Some of these underpressurized rods were shipped to Quad Cities-1 for Reload 5, cycle 6 (Refs. 101-103). The NRC estimated that less than 100 rods are actually involved in the 122 suspect fuel assemblies. There were also some of these underpressurized gadolinia fuel rods in two fuel assembiies that were shipped to Vermont Yankee (Ref. 102).

The problem was evaluated by the NRC, the vendor (General Electric Company), and the 1icensee (Commonwealth Edison) for Quad Cities-1 (Ref. 102). It was concluded that no unreviewed safety questions are involved and that no safety hazard exists as a result of this problem. The conclusions apply to Quad Cities-1 and to Vermont Yankee.

The licensee for Quad Cities-1 was advised that some degree of on-line and end-of-cycle surveiliance of these assemblies is appropriate.

After the weld station was repaired by the vendor, no new incidents have occurred. 


\subsubsection{PWR Hold-Down Spring Damage}

During 1980, information was received by the NRC that broken hold-down springs had been observed un fuel assemblies at three domestic and two foreign PWRs. The function of hold-down springs on fuel assemblies is to provide axial restraint to prevent coolant flow forces from causing movement of the fuel assemblies.

During the May-June 1980 period, broken hold-down springs were detected (by inspection and review of video tapes) at two domestic PWRs, Davis-Besse-1 (Refs. 104-106) and 0conee-1 (Refs. 107-109). At that time, the cause of the problem had not been conclusively defined; it was presumably due to improper material condition and high cycle fatigue. The fuel vendor for the domestic plants, Babcock \& Wilcox, was evaluating the problem (Ref. 107).

Ultimately, 1581 springs were examined and a total of 26 broken springs were found (Refs. 13, 108, and 110): 20 failed springs were identified in Cycle 1 fuel assemblies at Davis-Besse-1, five springs (in the 686 fuel assemblies inspected) at 0conee-1, one spring at Crystal River-3, and none at Rancho Seco, Three Mile Island-1, and Arkansas-1. The spring failure at Crystal River -3 is believed to have occurred solely by fatigue (Ref. 110).

The NRC prepared a list of questions regarding the recently detected hold down spring problem and transmitted the list to all Babcock \& Wilcox licensees (Ref. 111).

As requested by the NRC letter, Toledo Edison, the licensee of DavisBesse-1, prepared responses to questions related to this matter (Ref. 106). One response in Reference 106 indicated that six tests had been performed to determine the impact of broken hold-down springs on reactor operation and fuel integrity. It was concluded that long-term operation under the condition of damaged springs would at worst result in damage to some peripheral fuel rods, there is no possibility of damage resulting in non-insertion of control rods, 
wear from horizontal vibration will not be a significant problem, and severe vibration will not result for a lifted assembly. Another response in Reference 106 indicated that the cause of the hold-down spring failures was an improper material condition characterized by a coarse outer grain structure. To date, the corrective action recommended by Babcock \& Wilcox has been the replacement of all damaged springs with ones made to a current specification. The replacement springs have a uniform fine grain size, which provides increased fatigue resistance.

The NRC prepared a safety evaluation of the issues regarding Babcock \& Wilcox fuel assembly hold-down spring failures (Ref. 110). The NRC considered the spring failures to be a generic issue. The NRC review indicates that the predominant mode of faiture appears to have been fatigue-initiated cracking, followed by stress-corrosion crack propagation to failure of springs with an improper metallurgical condition (grain size). The NRC believes that there is reasonable assurance that the hold-down spring failures will not occur on as large a scale again, and that neither the potential for a) loss of positive hold-down force, b) loose parts, nor c) interference for normal control rod assembly movement constitute a significant safety hazard. However, because at least one spring failure (at Crystal River-3) appears not to be related to material of improper metaliurgical condition (i.e., stress-corrosion cracking), and because some lateral and vertical motion of loose assemblies is theoretically possible under certain (extreme) conditions, the NRC concludes that further surveillance (e.g., video examination) of the assembly hold-down springs should be carried out at the next refueling at each plant. All the licensees have comitted to such surveillance.

In 1980, broken hold-down springs were found at two foreign PWRs, which are Westinghouse Upper Head Injection (UHI) type reactors (Ref. 112). Inspection of all 132 hold-down assemblies at the first plant revealed that 31 contained springs that were either cracked or broken; inspection at the second plant disclosed 9 cracked or broken springs out of 132 .

The NRC issued a request (Ref. 113) to obtain the concurrence of the foreign utility company associated with one of those PWRs, Ohi-1, in releasing information concerning the defective hold-down springs there that were 
manufactured by Westinghouse. A response (Ref. 114) was subsequently received that included the follawing comments: the problem applies only to UHI plants, it has not been observed in any plant other than Ohi-1 (which lends credence to the UHI factor), (a) the Ohi-1 springs are "barrel"-shaped whereas springs at domestic Westinghouse plants are not (therefore, the problem may never be encountered in domestic plants), and there was no evidence of loose parts at Ohi-1. Sequoyah and MCGuire are the only domestic UHI plants, and, as of the end of 1980, neither plant had begun commercial operation (b) (Ref. 115). Westinghouse and the licensee (Tennessee Valley Authority) for Sequoyah reviewed the problem and determined that there was "no substantial safety hazard." Subsequentiy, the NRC requested (Ref. 116) an assessment of the holddown assenbly spring question by the licensee (Duke Power Company) for McGuire. The licensee's response (Ref. 112) indicated that arrangements have been made with Westinghouse to substitute hold-down assembly springs of a new design (discussed below) on a 11 McGuire nonfuel-bearing components that will be used for more than one cycle of operation (thimble plug and secondary source assemblies). Existing hold-down assembly springs will be used on McGuire nonfuelbearing components that will be used only for the first cycle of operation (burnable poison and primary source assemblies). The Westinghouse safety evaluation (Ref. 112) indicates that the operation of one cycle with the existing hold-down assembly springs does not constitute a safety problem.

Westinghouse is cooperating with the utilities involved to minimize further use of springs of the design that failed. A modified spring design has been developed to minimize the potential for failure by fatigue (Ref. 62).

\subsubsection{Iodine Spiking}

Iodine spiking (i.e., a temporary increase in coolant iodine concentration) is frequentiy observed at reactors where leaking fuel rods are present.

(a) Later information (Ref. 112) indicated that broken springs were found in a second foreign UHI-type PWR.

(b) Initial criticality was achieved at Sequoyah-1 on July 5, 1980, and electrical energy was first generated on Ju1y 22, 1980 (Ref. 117). The fuel loading date for McGuire-1 was Novenber 1980 (Ref. 118). Initial criticality was attained at McGuire-1 on August 8, 1981, and electrical energy was first generated on September 12, 1981 (Ref. 117). 
These temporary increases in iodine concentrations have been observed to occur following shutdowns, start-ups, rapid power changes, and coolant depressurization. Iodine spikes are characterized by a rapid increase in coolant concentration by as much as three orders of magnitude, followed by a return to pre-spike concentrations. The latter characteristic distinguishes the spiking phenomenon from a step-wise permanent increase in coolant activity level caused by the sudden failure of one or more fuel rods.

The NRC has developed Standard Technical Specifications (Table 13) for primary coolant iodine concentrations that make allowance for iodine spikes by permitting temporary excursions (not to exceed 48 hours) above the "equilibrium" concentration limit. For each excursion above the equilibrium limit, a Licensee Event Report is required. Four BWRs (Brunswick-1 and -2, Hatch-2, La Crosse) and approximately one-half of the operating PWRs have this type of technical specification.

During 1980, five reactors reported iodine spikes exceeding the equilibrium iodine limit: one BWR, Brunswick-2, and four PWRs, Arkansas-2, Crystal River-3, Davis-Besse-1, and St. Lucie-1.

The cause of the events is attributed to the presence of a small rumber of leaking fuel rods and a reactor coolant transient (e.g., reactor shutdown or the subsequent startup). However, in the case of Arkansas-2 (Ref. 119), the licensee attributed the iodine spike to a "crud burst".

On November 13, 1980, the reactor coolant system dose equivalent jodine-131 at Brunswick-2 (Ref. 120) exceeded the equilibrium Technical Specification limit of $0.2 \mu \mathrm{Ci} / \mathrm{g}$ of iodine-131 (dose equivalent) because of a reactor scram and the subsequent increase in fission product inventory coming from a leaking fuel bundle. The fuel bundles were to be sipped during the next refueling outage and the leaking fuel bundles were to be removed from the core. A similar occurrence (and similar corrective action) took place in November 1979 (Ref, 121). The reactor coolant activity also exceeded the equilibrium limit three times in 1980 (as a result of reactor shutdown on 0ecember 9 and reactor startups on December 12 and 18) (Ref. 122). The coolant iodine activity was controlled in one event by maintaining a constant coolant 
TABLE 13. Technical Specifications for Primary Coolant Activity(a)

\begin{tabular}{|c|c|c|c|c|}
\hline \multirow[b]{2}{*}{ Plant } & \multirow[b]{2}{*}{ Type ${ }^{(b)}$} & \multicolumn{3}{|c|}{ Limits on Coolant Activity } \\
\hline & & $\begin{array}{c}\text { Dose } \\
\text { Equivalent } \\
\text { Iodine-131, } \\
(\mu \mathrm{i} / \mathrm{g})\end{array}$ & $\begin{array}{l}\text { Other Iso- } \\
\text { topes } \\
\text { value/E (c) }\end{array}$ & Standard $(\mathrm{d})$ \\
\hline Arkansas $-1(\mathrm{e})$ & PWR & 3.5 & $75 / \bar{E}$ & No \\
\hline Arkansas-2 ${ }^{(f)}$ & PWR & 1.0 & $100 / \bar{E}$ & Yes \\
\hline Beaver Valley-1 & PWR & 1.0 & $100 / \bar{E}$ & Yes \\
\hline Big Rock Point-1 & BWR & (g) & (g) & -- \\
\hline Browns Ferry $-1,-2$, and -3 & BWR & 3.2 & (g) & No \\
\hline Brunswick-1 and-2 & BWR & 0.2 & $100 / \overline{\mathrm{E}}$ & Yes \\
\hline Calvert Ciiffs-1 and -2 & PWR & 1.0 & $100 / \bar{E}$ & Yes \\
\hline Cook-1 and -2 & PWR & 1.0 & $100 / \bar{E}$ & Yes \\
\hline Cooper Station & BWR & 3.1 & (g) & No \\
\hline Crystal River-3 & PWR & 1.0 & $100 / \vec{E}$ & Yes \\
\hline Davis-Besse-1 & PWR & 1.0 & $100 / \bar{E}$ & Yes \\
\hline Dresden-1 & BWR & $20.0^{(h)}$ & (g) & No \\
\hline Dresden-2 & BWR & $20.0^{(h)}$ & (g) & No \\
\hline Dresden-3 & BWR & $20.0^{(h)}$ & (9) & No \\
\hline Duane Arnold & BWR & 1.2 & (9) & No \\
\hline Farley-1 & PWR & 1.0 & -- & No \\
\hline Fitzpatrick & BWR & 3.1 & (g) & No \\
\hline Fort $C$ al houn-1 & PWR & 2.0 & $21 / \vec{E}$ & No \\
\hline Ginna & PWR & 3.0 & $54 / \bar{E}$ & No \\
\hline Haddam Neck & PWR & (g) & $68 / \overline{\mathrm{E}}$ & No \\
\hline Hatch-1 & BWR & 10 & (g) & -- \\
\hline Hatch-2 & BWR & 0.2 & $10 \dot{0} / \bar{E}$ & Yes \\
\hline Indian Point-2 & PWR & (g) & $60 / \overrightarrow{\mathrm{E}}$ & No \\
\hline Indian Point-3 & PWR & 1.0 & $100 / \overline{\mathrm{E}}$ & Yes \\
\hline Kew aunee & PWR & (g) & $91 / \overrightarrow{\mathrm{E}}$ & No \\
\hline La Crosse & BWR & 0.2 & $100 / \overrightarrow{\mathrm{E}}$ & Yes \\
\hline Maine Yankee & PWR & 1.0 & $100 / \vec{E}$ & Yes \\
\hline Millstone-1 & $B W R$ & $20.0^{(h)}$ & (g) & No \\
\hline Millstone-2 & Pw'R & 1.0 & $100 / \bar{E}$ & Yes \\
\hline Monticello & BWR & 5.0 & (g) & No \\
\hline Nine Mile Point-1 & BWR & $25.0^{(h)}$ & (g) & No \\
\hline North Anna-1 and-2 & PWR & 1.0 & $100 / \overline{\mathrm{E}}$ & Yes \\
\hline 0conee $-1,-2$, and -3 & PWR & (g) & $224 / \bar{E}$ & No \\
\hline Oyster Creek-1 & BWR & $8.0^{(h)}$ & (g) & No \\
\hline
\end{tabular}


TABLE 13. (contd)

\begin{tabular}{|c|c|c|c|c|}
\hline \multirow[b]{2}{*}{ Plant } & \multirow[b]{2}{*}{ Type ${ }^{(b)}$} & \multicolumn{3}{|c|}{ Limits on Coolant Activity } \\
\hline & & $\begin{array}{c}\text { Dose } \\
\text { Equivalent } \\
\text { Iodine-131, } \\
(\mu \mathrm{C} / \mathrm{g}) \\
\end{array}$ & $\begin{array}{l}\text { Other Iso- } \\
\text { topes, } \\
\text { value/E) }\end{array}$ & Standard (d) \\
\hline Palisades & PWR & 1.0 & $100 / \tilde{E}$ & Yes \\
\hline Peach Bottom-2 and-3 & BHR & 2.0 & (g) & No \\
\hline Pilgrim-1 & BHR & $20.0^{(\mathrm{h})}$ & (g) & No \\
\hline Point Beach-1 and -2 & PWR & (g) & $162 / \overline{\mathrm{E}}$ & No \\
\hline Prairie Island-1 and-2 & PWR & (g) & $27 / \overline{\mathrm{E}}$ & No \\
\hline Quad Cities-1 and-2 & BWR & 5.0 & (g) & No \\
\hline Rancho Seco-1 & PWR & (g) & $43 / \vec{E}$ & No \\
\hline Robinson-2 & PWR & 1.0 & $100 / \bar{E}$ & Yes \\
\hline Salem-1 & PWR & 1.0 & $100 / \vec{E}$ & Yes \\
\hline San 0nofre-1 & PWR & 1.0 & $100 / \bar{E}$ & Yes \\
\hline Saint Lucie-1 & PWR & 1.0 & $100 / \vec{E}$ & Yes \\
\hline Surry-1 and-2 & PWR & 1.0 & $43 / \vec{E}$ & No \\
\hline Three Mile Island-1 & PWR & (g) & $130 / \overline{\mathrm{E}}$ & No \\
\hline Three Mile Island-2 & PWR & 1.0 & $100 / \overline{\mathrm{E}}$ & Yes \\
\hline Trojan & PWR & 1.0 & $100 / \overline{\mathrm{E}}$ & Yes \\
\hline Turkey Point-3 and-4 & PWR & 1.0 & $135 / \overline{\mathrm{E}}$ & No \\
\hline Vermont Yankee-1 & BWR & 1.1 & (g) & No \\
\hline Yankee Rowe-1 & PWR & 1.0 & $100 / \overline{\mathrm{E}}$ & Yes \\
\hline Zion-1 and-2 & PWR & (g) & $57 / \overline{\mathrm{E}}$ & No \\
\hline
\end{tabular}

(a) As of September 1980 .

(b) Pressurized water reactor (PWR), boiling water reactor (BWR).

(c) $\bar{E}$ = average disintegration energy, (MeV).

(d) Standard Technical Specifications:

BWR Activity:

$0.2 \mu \mathrm{Ci} / \mathrm{g}$, Dose Equivalent Iodine-131, and $100 / \overline{\mathrm{E}} \mu \mathrm{Ci} / \mathrm{g}$, equilibrium

4.0 $\mathrm{\mu C} / \mathrm{g}$, Dose Equivalent Iodine-13l during iodine spikes

PWR Activity:

$1 \mu \mathrm{Ci} / \mathrm{g}$, Dose Equivalent Iodine-131, and $100 / \bar{E} \mu \mathrm{Ci} / \mathrm{g}$, equilibrium $60 \mu \mathrm{Ci} / \mathrm{g}$, Dose Equivalent Iodine-131 during iodine spikes (some plants have higher spiking limits for decreasing power levels).

(e) Arkansas Nuclear One-Unit 1.

(f) Arkansas Nuclear Dne-Unit 2.

(g) Not available or nonexistent.

(h) Technical Specification stated as total iodine $(\mu \mathrm{Ci} / \mathrm{g})$ instead of equivalent iodine-131. 
temperature and in two events by limiting reactor power. To eliminate future similar occurrences, the fuel bundles will be sipped by the licensee during the next refueling autage and the leaking fuel bundles removed from the core. (a)

The reactor coolant system dose equivalent iodine-131 at Crystal River-3 exceeded the equilibrium Technical Specification $3.4 .81 \mathrm{imit}$ of $1.0 \mu \mathrm{Ci} / \mathrm{g}$ on December 21, 1979 (Ref. 123), February 8, 1980 (Ref. 124), February $g$ and 11, 1980 (Ref. 125), and December 8, 1980 (Ref. 126). The five events were caused by leaking fuel rods in combination with a reactor coolant system transient (i.e., power reduction, plant trip, shutdown, or startup). The event in December 1980 was the nineteenth occurrence reported under this specification. References 123 and 125 indicate that no corrective action was deemed necessary by the licensee as the coolant system purification returned the dose equivalent iodine-131 to within acceptable limits. Reference 124 and 126 indicate that the licensee's corrective action was to increase the reactor coolant purification flow to aid cleanup. In 1980, the Core Performance Branch of NRC (Ref. 127) attempted to leam more about the nature of the fuel failures but has been unable to determine the exact number or types of fuel failures.

On December 3, 1980, the dose equivalent jodine-131 level at Davis-Besse-1 (Refs. 128 and 129) exceeded the equilibrium Technical Specification 3.4.8a $1 \mathrm{imit}$ of $1.0 \mu \mathrm{Ci} / \mathrm{g}$. The cause was a slight leakage of gas through the fuel rod cladding. The licensee also indicated that some leakage is not unusual following a reactor trip (as in this case) when the gases in the fue 1 rods are further compressed by the contracting cladding. The levels were monitored by the licensee to ensure that the coolant activity decayed off to below limits. There have been no prior reports of high iodine levels at Davis-Besse-1.

During a short (12-hr) shutdown on August 14, 1980, at St. Lucie-1 (Ref. 130), while in a startup mode, the dose equivalent iodine exceeded the equilibrium Technical Specification 3.4.8.a $1 \mathrm{imit}$ of $1.0 \mu \mathrm{Ci} / \mathrm{g}$. After an extended period of power operation with a nominal level of fuel leakage, a dropped control element assembly and the plant shutdown were sufficient

(a) As of December 31, 1980 (Ref. 115) and August 1, 1981 (Ref. 117), the next refueling outage had not been scheduled yet. 
transients to cause the iodine build-up (iodine spiking phenomenon). The dose equivalent iodine-131 level decreased to below the limit after 8.5 hours.

The licensee stated in a January 1980 report (Ref. 56), that they suspected that failed fuel rods were present in Maine Yankee, based on the results of reactor coolant chemistry monitoring through Cyc le 4. In 1979, the reactor coolant dose equivalent iodine exceeded the Technical Specification 3.21 imit of $1.0 \mu \mathrm{Ci} / \mathrm{g}$ several times, as noted in Licensee Event Reports 79-010, 79-017, 79-029 (Ref. 55), and 79-030 (Ref. 57). The increases in iodine levels were anticipated during the load reductions (i.e., shutdowns) because of the known existence of minor degradation of fuel rod cladding. The licensee had established a monitoring program to follow the iodine trends and planned to conduct fuel sipping during the next refueling outage (Refs. 55 and 57). The fuel was inspected and the results are described in Section 3.1.3.1.

At Arkansas-1, which does not have the Standard Technical Specifications for coolant activity, the average gross gas release rate during the first quarter of 1980 (Ref. 131) exceeded Environmental Technical Specification 2.4.2.1 and the average gross gas release rate during the third quarter of 1980 (Refs. 132 and 133) exceeded Environmental Technical Specification 2.4.2.3a. Reference 131 indicated that the activity levels were higher than previous levels due to an apparent increase in failed fuel (less than $0.1 \%$ failed fuel) and that the fuel should be replaced within two cycles. Reference 132 indicated that the activity was higher than in the past because of approximately $0.08 \%$ failed fuel and that the problem will be corrected when the failed fuel is removed from service. Reference 134 indicated that the quarterly releases were significantly impacted by two shutdowns during the third quarter and also the presence of approximately $0.19 \%$ failed fuel and that the licensee will make an attempt to identify, replace or repair the failed fuel at the next refueling outage. In February 1981, the licensee inspected the full core of 177 fuel assemblies by wet sipping (a standard gammaspectrometer was used to identify iodine-131, cesiun-134, and cesium-137 isotopes and quantify their activities in the liquid sipping samples) and identified 24 fuel assemblies with leaking fuel rods and tentatively planned to 
reinsert five of those assemblies for operation in Cycle 5 in the core outer periphery. The above information is being evaluated by NRC staff (Ref. 135).

Although iodine spiking has not caused serious problems, the NRC and the industry have already taken the initiative to encourage the investigation of the cause and impact of iodine spiking. One area of interest is to predict from iodine spiking when and where fuel failures occur. Babcock \& Wilcox reported (Ref. 136) on a study of this subject for EPRI in October 1980 . The on-line monitor, a minicomputer-controlled system, used in the study indicates the iodine fission product concentrations in the coolant as a function of time. By instaling the monitor at Oyster Creek, it was possible to determine the presence of fuel defects in the core through interpretation of the data.

\subsubsection{Alpha Activity in Coolant)}

Gross alpha activity in the primary coolant at La Crosse (Refs. 137-139) exceeded the Technical Specification level during reactor shutdown. The high alpha activity indication was temporary and did not indicate recent fue 1 cladding degradation. Reference 138 indicates that this is the fourth occurrence (other three are noted in Licensee Event Reports 80-06, 79-10, and 78-05). The activity is associated with the irradiated fuel material in the reactor coolant system, which is a result of the degraded fuel rod cladding experienced during previous fuel cycles. Also, work was done on the forced circulation system during the shutdown and this resulted in a more general distribution of suspended alpha-bearing material in the coolant. Operation of the purification system for the primary coolant reduced the concentration to an allowable value.

\subsubsection{Misoriented Fuel Assemblies}

There have been instances of misoriented fuel assemblies in previous years. Three cases occurred in 1980.

A peripheral fuel asssembly at Browns Ferry-1 (Ref. 140) was found to be rotated 90 degrees from required orientation during a review of core verification video tapes. During the previous refueling outage at the beginning of Cycle 4 , that fuel assembly was improperly oriented. There was no activity release; there was ample margin to operating limits to ensure that limits were not exceeded. A revision of core verification methods is being implemented. 
Two fuel assemblies at Browns Ferry-2 (Ref. 141) were found misoriented 90 degrees out of proper orientation during fuel shuffling operatons. These two misoriented assemblies were detected during initial reloading verification but were not corrected. The fuel assemblies operated within the bounds of the reload licensing submittal. Core verification procedures will be improved to prevent recurrence.

A fuel assembly at 0yster Creek-1 (Refs. 142 and 143) was found to be misoriented 180 degrees during a fuel bundle clip inspection prior to sipping. The assembly was not properly seated in its core cell location. The cause was attributed to personnel error and inadequate procedural controls. Revisions to the procedures were made (e.g., a fuel bundle orientation map is now included). The fuel assembly was inspected by the vacuum sipping method; the results indicated that no cladding failure had occurred.

\subsubsection{Other Occurrences}

A fuel assembly at Duane Arnold (Ref. 144) was loaded into the cell without having the neighboring control rod fully inserted. The incident was caused by personnel error. The fuel handling procedure is now being revised for clarity, and personnel will be retrained as necessary.

During fuel shuffling operations at Browns Ferry-2 (Ref. 145), fuel was placed in a cell with the adjacent control rod withdrawn. This was caused by a deficient procedure for fuel support casting replacement. The control rod was subsequently inserted and refuel interlocks placed in service. The procedure will be revised to correct the deficiencies.

A fuel assembly at Quad Cities-1 (Ref. 146) was moved prematurely during the end of Cycle 5 core unload. The cause was a misunderstanding of a recent Technical Specification change. Corrective action will be taken so that the use of changes to Technical Specifications will be restricted until either the advance copy or final printed copy is onsite and distributed.

The measured $F$ values (deIta $H$ ) at North Anna-1 (Ref. 147) for control rod insertion exceeded design value tolerance because of the presence of a quadrant power tilt, identified through incore flux map analyses, and is believed to be the result of non-symmetric isotopic distribution in the fuel caused by the 
Cycle 1 quadrant power tilt. Control rod insertion limits have been revised. An investigation is underway to determine the primary cause of the power tilt.

Two sealed specimens and fuel racks in the spent fuel pool at Kewaunee-1 (Ref. 148) exhibited swelling. The cause was attributed to gaseous products of radiolysis of materials used in boron carbide plates in spent fuel pool canisters and rack specimens. The immediate action taken was to rearrange the spent fuel bundles in a "checkerboard" pattern. An investigation is underway by the licensee to determine long-term corrective actions.

The spent fuel pool level at Davis-Besse-1 (Ref. 149) was found $15.9 \mathrm{~cm}$ (6.25 in.) below Technical Specification requirements (there must be $7.0 \mathrm{~m}$ or $23 \mathrm{ft}$ of water above the top of the assemblies) due to an improper alarm set point. Water level was restored in $2 \mathrm{hr}$. The set point was changed.

Deficiencies in documentation of the design and fabrication of the high density spent fuel storage racks for Watts Bar-1 (Ref. 150) were found in an audit of the supplier's quality assurance program. Possible radionuclide release could result from a seismic event which collates the racks. Investigation of this matter is underway.

\subsection{OLD PROBLEMS (1979) THAT DID NOT REOCCUR OR THAT WERE SOLVED}

\subsubsection{PWR Guide Tube Wear}

Wear of control rod guide tubes has been observed in discharged PWR fuel assemblies since 1973. The cause of this wear was identified as flow-induced vibration of control rods. A survey of the measures taken by both the industry and the NRC to deal with this matter is described in a recent report (Ref. 71 ). A summary of the events that occurred during 1979 was presented in Reference 2. The licensing actions during 1979 are discussed in Reference 151.

Several vendors and licensees have taken corrective actions to alleviate the guide tube wear problem in 1980: Combustion Engineering has placed flowmodifying test assemblies in five reactors, performed surveillance on guide tube integrity in five reactors, and concluded that the use of sleeves (recommended in 1979) continued to be a satisfactory preventive method. An owner's group of Babcock \& Wilcox reactors was formed and submitted the details of a 
surveillance program conducted in 0conee-1 and -3 and Rancho Seco. The program is being evaluated by the NRC. Exxon Nuclear performed surveillance on fuel assemblies discharged from H. B. Robinson-2, and reported that the measured wear did not extend through the guide tube walls.

Because of effective hardware modifications and satisfactory confirmatory surveillance, guide tube wear is considered to be under effective control. However, in 1980 the Core Performance Branch of NRC, requested additional information on guide tube wear characteristics for use in reviewing applications for North Anna-2 (Ref. 152), Diablo Canyon-1 and -2 (Ref. 153), McGuire-1 and -2 (Ref. 154), and Sequoyah-1 and -2 (Ref. 155). The NRC prepared updated inputs for the Safety Evaluation Reports (SERs) for North Anna-2 (Ref. 156), Diablo Canyon-1 and -2 (Ref. 157), and Salem-2 (Ref. 158), which closes out the issue of guide tube thimble wear in the operating license applicatons for those plants. In those references, the NRC staff concluded that the Westinghouse analysis probably accounts for all major variables controlling this wear process. However, because of the complexities and undertainties in determining a) contact forces, b) surface-to-surface wear rates, c) forcing functions, and d) extrapolations of these variables to other fuel designs (such as the $17 \times 17$ fuel assenty design in North Anna-1, Diablo Canyon-1 and -2, and Salem-2), the NRC believes it is prudent for each of the applicants to participate in a surveillance plan for the examination of guide thimble wear.

\subsubsection{Westinghouse Control Spider Rodlet Failures}

The cause of this type of failure was determined by the NRC to be a manufacturing problem and not a generic design error. No failure of this type was reported during 1980 .

\subsubsection{Other Problems in 1979 That Did Not Reoccur in 1980}

Some problems in 1979 (Ref. 2) did not reoccur in 1980. Those problems, plus recent information of interest, are shown below:

- Cracking of Stainless Steel Cladding on PWR Fuel Rods

In February 1979, Haddam Neck (Connecticut Yankee) reported detecting (by sipping and visual inspection during the Cycle 9 refueling 
outage) 36 leakers among 48 Core 8 , Batch 8 fuel assemblies (Ref. 2). The NRC noted (Ref. 159) that the most surprising result from the postirradiation examination was the observation of several incipient cracks (i.e., cracks that do not extend through the cladding wall) that initiated from the outer surface of the stainless steel cladding, in contrast to typical pellet-cladding-interaction (PCI) cracks in Zircaloy cladding that initiate on the inner surface of the cladding.

Preliminary evaluations and conclusions frm the hot cell examination are presented in a November 1980 interim report (Ref. 160). In each of three specimens, 1) the cracks in the cladding originated from the outer surface, 2) the cracks were intergranular in nature, and 3) a fuel chip wedged in the fuel-cladding gap was noted directly across from the crack in the cladding. The investigators "tentatively concluded that high local cladding stresses, caused by the presence of the fuel chip, were the primary cause of cracking in the cladding and that the fuel rod failures may have occurred by the same mechanism. Additional work is in progress to verify this conclusion."

The licensee (Connecticut Yankee Atomic Power Company) evaluated iodine-131 activity trends: activity decreased during Cycle 9 when compared to Cycle 8; Cycle 9 activity was still higher than Cycle 7 and two to ten fuel rods were predicted to be defective (Ref. 161). Although the coolant activity was not limiting, the licensee inspected fuel during the Core 10 refueling outage. All 52 Batch 9 discharged fuel assemblies were sipped: $11.5 \%$ were found to be leaking ( 6 were leaking, 1 was possibly leaking, and 45 were sound). Seventeen of the assemblies (included the seven known or possible leakers) were visually inspected by periscope; the visual inspection was documented with color photographs. Approximately 950 fuel rods were visually inspected and no failures (as exhibited in Core 8 , Batch 8 fuel) were found and no failures of the fuel rod cladding similar in visual characteristics to those observed during the inspection of core 8 , Batch 8 fuel were apparent. The licensee 
indicated that no one parameter for the Batch 9 fuel assemblies can be identified conclusively as a common parameter affecting the probability of failure; however, burnup seems to have some bearing on the failure probability (e.g., the failures were associated with fuel assemblies that had attained burnups greater than 33,000 MWd/MTU). Further investigations are underway by the licensee.

- BWR Water Rod Lower End Plug Wear

In October 1979, water rod end plug wear was observed at Vermont Yankee (Ref. 2). The NRC issued an information notice (Ref. 162) regarding this wear problem. Water rod lower end plug inspection results are described by General Electric in Reference 163. In 1980, a submittal for Vermont Yankee Reload 7 did not indicate how the licensee would address and resolve this problem; as a result, the NRC transmitted a number of questions to the licensee (Ref. 92). In response, the licensee indicated (Ref. 94) that the lower end plug configuration had been changed "to incorporate the design of earlier fuel types which have not exhibited wear" and that future end plug inspections would be consistent with General Electric's recommendations as part of their generic investigation into the problem.

- BWR Control Blade Cracking

Movable blades comprised of many small rods containing $B_{4} C$ are used to control power in BWRs. As noted in the previous annual report (Ref. 2), cracks in control rod cladding have been observed recently. However, no Licensee Event Reports invoiving BWR control rod cracking were submitted to the NRC in 1980. The early estimate of control blade life was 12 cycles, a later estimate was 28 cycles, and, as a result of the recently observed cracking, the current estimate is 6.4 cycles (Ref. 164).

A recent paper (Ref, 165) describes the results of the postirradiation examination of a defective control rod (had cracks in cladding of the $B_{4} C$ absorber rods) that had been irradiated for eight years in a foreign $B W R, K R B(A)$. 
- Extensive Core Damage (Three Mile Island-2)

Three Mile Is 1 and-2 (TMI-2) has remained shut down since the accident on March 8, 1979, which caused extensive core damage (Ref. 115). Authority to operate the facility was suspended by the NRC on July 20, 1979, which requires the licensee to maintain the facility in a shutdown condition. As described in the previous report (Ref. 2), the accident prompted a large number of investigations into the accident, the behavior of the reactor during the accident, and related subjects. Summaries of many papers dealing with the accident or related studies have been published recently: there are 55 in Reference 166, 20 in Reference 167, and 3 in Reference 168. The final definition of the damage to the core of TMi-2 will have to wait until a detailed examination of the TMI-2 core and primary system has been performed (Refs. 169-171). The scenario that the NRC believes to be the most likely for the progression of the damage to the TMI-2 core is described in a recent paper (Ref. 172). In 1980, EPRI issued a bibliography of material related to Three Mile Island-2 (Ref. 173). 



\subsection{FUEL DESIGN CHANGES}

Several programs are assessing the commercial acceptability of improved fuel concepts in an effort to solve the pellet-cladding interaction (PCI) problem $^{(a)}$ and to improve uranium utilization. (b)

The ultimate objective of a program at General Electric (Refs. 174 and 175$)$ is to demonstrate an advanced fuel design that is resistant to the PCI fuel failure mechanism. Two advanced fuel concepts are being developed for possible demonstration within this program: a) Cu-barrier fuel and b) Zr-liner fuel. Four lead test assemblies of barrier fuel (two of Zr-liner and two of Cu-barrier) were examined at the end of one full cycle of operation in Quad Cities-1 (Table 2). The bundle average burnup was 11,700 MWd/MTU. The program intends to include a total of 132 barrier bundles in the reload for Cycle 6 at Quad Cities-2.

In the Consumers Power Company/ENC/PNL Fuel Performance Improvement Program (Refs. 176-178), an annular-coated-pressurized design and a sphere-pac design are being evaluated by means of steady-state and ramping irradiations and their performance is being compared with a reference fuel design. Four fuel assemblies containing demonstration fuel rods were inserted in Big Rock Point during the spring of 1979 (see "rods" under ENC in Table 2).

As shown in Table 2, irradiation of other fuel assemblies with design changes (e.g., use of an optimized design, low absorption spacer grids, or axially blanketed fuel columns) is underway.

The EPRI programs (Ref. 52) were discussed in Section 2.2.6.

The Department of Energy (DOE) has programs that involve extended burnup demonstrations of current product-line fuel. DOE is sponsoring (or has sponsored) such programs with the following (utility/fuel vendor/reactor):

(a) PCI is the principal concern regarding fuel failure at higher burnup with present LWR fuel (Ref. 179). The PCI phenomenon is generic to reactors using Zircaloy-clad $\mathrm{U0}_{2}$ fuel (Ref. 180).

(b) For example, uranium utilization can be improved by having fuel go to higher burnup, by reducing neutron absorption, or by reducing neutron leakage. 
- Duke Power Company/Babcock \& Wilcox/0conee-1

- Omaha Public Power District/Combustion Engineering/Fort Calhoun

- Arkansas Power \& Light Company/Combustion Engineering/Arkansas-2

- Virginia Electric \& Power Company/Westinghouse/Surry-2

- Northern States Power Company/General Electric/Monticello

- Consumers Power Company and GPU/Exxon Nuclear/Oyster Creek and Big Rock Point

- --/Westinghouse/BR-3

Five Mark B (15x15) PWR fuel assemblies designed by Babcock \& Wilcox were irradiated to extended burnups in Oconee Unit 1 (Ref. 25). An assembly average burnup of 40,000 MWd/MTU was attained. Efforts during this period included performance tracking of the extended burnup assemblies, nondestructive examination of the four-cycle assemblies, and analytical work to identify and quantify the factors that limit fuel assembly lifetime.

B\&W, DOE, and Sacramento Municipal Utility District are participating in an axial blanket fuel demonstration program (Ref. 181), which is part of U.S. effort to improve uranium utilization in LWRs.

The Improved Uranium Utilization Program at General Electric (Ref. 182) includes a Phase I evaluation of BWR design alternatives that have potential to reduce uranium ore requirements in once-through fuel cycles. Emphas is is being placed on developing practical alternatives which can be demonstrated at the earliest possible date in existing operating BWR nuclear power stations. Priority is being given to alternatives which have the maximum payoff, measured by reduction of the nation's uranium resource requirements, on the shortest schedule.

The purpose of one program at Combustion Engineering (Ref. 183) is to demonstrate two techniques for improving fuel utilization in current PWRs: 1) more efficient fuel management, and 2) high burnup. These demonstrations are being performed in the Fort Calhoun reactor. The current Phase I program will be accomplished in two parts: one to demonstrate SAVFUEL (Shimaned And 
Very Flexible Uranium Element Loading), which is expected to reduce uranium requirements by two to four percent ( $2 \%$ to $4 \%$ ), and the other to demonstrate high burnup.

The purpose of another program that is sponsored by DOE at Combustion Engineering (Ref. 184) is to develop gadolinium as a burnable poison in PWR extended-burnup, low-leakage fuel management schemes that achieve improved uranium utilization.

DOE, Virginia Electric and Power Company, and Westinghouse are participating in an Extended Fuel Burnup Demonstration Program (Ref. 185) to improve the utilization of fuel resources in LWRs. 



\section{U REFERENCES}

1. M. D. Houston, Fuel Performance Annual Report (Period through December 1978. NUREG-0633, U.S. Nuclear Regulatory Comission, December 1979.

2. M. Tokar, W. J. Bailey and M. E. Cunningham, Fuel Performance Annual Report for 1979. NUREG/CR-1818 (PNL-3583), U.S. Nuc lear Regulatory Commission, January 1981.

3. Regulatory Guide 1.16 through Revision 5, "Reporting of Operating Information--Appendix A Technical Specifications," 1971 to 1979.

4. W. J. Bailey, C. J. Morris, F. R. Reich, and K. L. Swinth, Assessment of Current Onsite Inspection Techniques for Light-Water Reactor Fuel Systems: Executive Sumary. NUREG/CR-1380 (PNL-3325), Vo T. 1, U.S. NuClear Regulatory Commission, July 1980.

5. Office of Operations Evaluation, Nuclear Power Plant Operating Experience Ouring 1973, O0E-ES-004, U.S. Atomic Energy Commission, December 1974.

6. Office of Management Information and Program Control, Nuclear Power Plant Operating Experience 1974-1975. NUREG-0227, U.S. Nuc lear Regulatory Commission, April 1977.

7. Office of Management Information and Program Control, Nuclear Power Plant Operating Experience 1976. NUREG-0366, U.S. Nuclear Regulatory Commission, December 1977.

8. M. R. Beebe, Nuclear Power Plant Operating Experience-1977: Annual Report, NUREG-0483, U.S. Nuclear Regulatory Comm ission, February 1979.

9. M. R. Beebe, Nuc lear Power Plant Operating Experience-1978: Annual Report, NUREG-0618, U.S. Nuclear Regulatory Comission, December T979.

10. R. L. Scott, O. S. Queener, and C. Kukielka, Nuclear Power Plant Operating Experience-1979: Annual Report, NUREG/CR-1496 (ORNL/NUREG/NSIC-180), Oak Ridge National Laboratory, Oak Ridge, Tennessee, May 1981.

11. U.S. Nuclear Regulatory Commisson Standard Review Plan, Rev. 1. NUREG-75/087 (present1y NUREG-0800).

12. V. Stello (NRC), Memorandum to R. C. DeYoung, "Supplemental Surveillance of $17 \times 17$ Fuel Assemblies," November 14, 1974.

13. J. H. Taylor (B\&W), Letter to M. Tokar (NRC), "B\&W 1980 Fuel Performance," June 10, 1981. 
14. 3. T. Mayer et al., "B\&W Radiochemical Analys is for Defective Fue, ," Babcock \& Wilcox Co., Lynchburg, Virginia. Paper presented at IAEA Specialist's Meeting on "The Behavior of Defected Zirconium Alloy Clad Ceramic Fuel in Water-Cooled Reactors," Chalk River, Canada, September 17-21, 1979.

15. "LER No. 80-015/01T-0," LER Monthiy Report (for May 1980), June 4, 1980 (p. 80). Docket No. $503 \overline{12 ~(R a n c h o ~ S e c o-1) . ~}$

16. R. Lobe] (NRC), Memorandum for P. S. Check (NRC), "Summary of Discussion with SMUD Concerning Fuel Fajlure at Rancho Seco," March 25, 1980.

17. Post-Irradiation Examination of Oconee 1 Fuel-Cyc le 1 Nondestructive Test Phase. BAW-1519, Babcock \& Wilcox, Lynchburg, Virginia, June 1979 (C00-4711-11).

18. Post-Irradiation Examination of 0conee 1 Fuel-Cycle 1 Destructive Test Phase. BAW-1535, Babcock \& Wilcox, Lynchburg, Virginia, July 1979 (COD-4711-23).

19. Post-Irradiation Examination of Oconee 1 Fuel-End of Cycle 2 Nondestructive Test Phase. BAW-1574, Babcock \& Wilcox, Lynchburg, Virginia, October 1979 (DOE/ET/34213-3).

20. T. D. Pyecha et al., Nondestructive Examination of 0conee 1 Fuel Assemblies After Four Cycles of Irradiation. BAW-1650, Babcock \& WiTcox, Lynchburg, Virginia, December 1980 (DOE/ET/34212-30).

21. T. D. Pyecha et a1., Nondestructive Examination of Oconee 1 Fuel Assemblies After Three Cyc les of Irradiation. BAW-1553, Babcock \& Wilcox, Lynchburg, Virginia, September 1980 (C00-4711-20).

22. Oconee Unit 1, Cycle 7--Reload Report. BAw-1660, Babcock \& Wilcox, Lynchburg, Virginia, March 1981.

23. T. A. Coleman et al., Qualification of the B\&w Mark B Fuel Assembly for Hjgh Burnup, First Semi-Annual Progress Report, July-December 1978. BAW1546-1, Babcock \& Wi\}cox, Lynchburg, Virginia, August 1979 (C00-4711-19).

24. T. A. Coleman et al., Qualification of the B\&w Mark B Fuel Assembly for High Burnup, Second Semi-Annual Progress Report, January-June 1979. BAW1546-2, Babcock \& Wi1cox, Lynchburg, Virginia, December 1979 (CO0-4711-24).

25. T. A. Coleman et a1., Qualification of the B\&W Mark B Fuel Assembly for High Burnup, Third Semi-Annual Progress Report, July-December 1979. BAW1546-3, Babcock \& Wilcox, Lynchburg, Virginia, September 1979 (DOE/ET/34212-27). 
26. T. A. Coleman et al., Qualification of the B\&w Mark B Fuel Assembly for High Burnup, Fourth Semi-Annual Progress Report, January-June 1980. BAW1546-4, Babcock \& Wilcox, Lynchburg, Virginia, September 1980 (DOE/ET/34212-28).

27. Oconee 1, Cycle 5 Design Report. BAW-1520, Babcock \& Wilcox, Lynchburg, Virginia, May 1979 (C00-4711-10).

28. Extended Burnup Lead Test Assembly Design Report. BAW-1626, Babcock \& WiTcox, Lynchburg, Virginia, October 1980.

29. T. A. Coleman et al., Development of an Extended-Burnup Mark B Design, First Semi-Annual Progress Report, July-December 1978. BAW-1532-1, Babcock \& Wilcox, Lynchburg, Virginia, November 1979 (DOE/ET/04712-1).

30. T. A. Coleman et al., Development of an Extended-Burnup Mark B Design, Second Semi-Annual Progress Report, January-June 1978. BAW-1532-2, Babcock \&ilcox, Lynchburg, Virginja, November 1979 (DOE/ET/34213-2).

31. T. A. Coleman et a1., Development of an Extended-Burnup Mark B Design, Third Semi-Annual Progress Report, July-December 1979. BAW-1532-3, Babcock \& Wilcox, Lynchburg, Virginia, March 1980 (D0E/ET/34213-4).

32. T. A. Coleman et al., Development of an Extended-Burnup Mark B Design, Fourth Semi-Annual Progress Report, January-June 1979. BAW-1532-4, Babcock \& Wilcox, Lynchburg, Virginia, September 1980 (DOE/ET/34213-6).

33. M. A. Hannah et al., Axial Blanket Fuel Design and Demonstration, First Semi-Annual Progress Report, January-September 1980. BAW-1643-1, Babcock \& Wilcox, Lynchburg, Virginia, November 1980 (D0E/ET/34020-1).

34. Axial Blanket Lead Test Assembly-Licensing Report. BAW-1664, Babcock \& Wilcox, Lynchburg, Virginia, March 1981.

35. R. J. Beauregard, Pre-Irradiation Characterization of Test Specimens in the Creep Collapse Program. LRC-4733-2, Babcock \& Wilcox, Lynchburg, Virginia, January 1977.

36. T. P. Papazoglou, Pre-Irradiation Characterization of Test Specimens in the PWR Demonstration Program. LRC-4733-1 (NP), Babcock \& Wi1cox, Lynchburg, Virginia, November 1975.

37. H. H. Davis, T. P. Papazoglou, and L. J. Ferre11, Poolside Examination of PWR Demonstration Fuel Assemblies and Creep Specimens-End of Cycle 1. LRC-4733-3, Babcock \& Wilcox, Lynchburg, Virginia, July 1977.

38. R. J. Beauregard, T. P. Papazoglou, and L. J. Ferrell, Hot Cell Examination of Creep Collapse and Irradiation Growth Specimens-End of Cycle 1. LRC-4733-4, Babcock \& Wilcox, Lynchburg, Virginia, July 1977. 
39. H. H. Davis, T. P. Papazoglou, and L. J. Ferre11, Poolside Examination of PWR Demonstration Fuel Assemblies and Creep Specimens-End of Cycle 2 .

LRC-4733-5, Babcock \& Wilcox, Lynchburg, Virginia, August 1978.

4D. G. M. Bain and T. P. Papazoglou, Hot Cell Examination of Creep Collapse 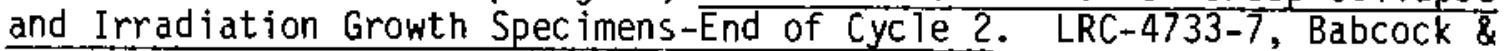 Wilcox, Lynchburg, Virginia, May 1979.

41. W. A. Pavinich and T. P. Papazoglou, Hot Cell Examination of Creep Collapse and Irradiation Growth Specimens--End of Cycle 3. LRC-4733-8, Babcock \& Wilcox, Lynchburg, Virginia, March 1980.

42. D. K. Thome, G. 0. Hayner, and T P. Papazoglou, Hot Cell Examination of PWR Demonstration Fuel Assemb ly 2B40. LRC-4733-6, Babcock \& Wilcox, Lynchburg, Virginia, February 1981.

43. Oconee Unit 2, Cycle 2-Reload Report (Rev. 1). BAW-1425 (Rev. 1), Babcock \& Wilcox, Lynchburg, Virginia, April 1976.

44. MK BZ Demonstration Assembly-Licensing Report. BAW-1533 (Rev. 1), Babcock \& Wilcox, Lynchburg, Virginia, March 1980.

45. Oconee Unit 2, Cycle 5-Reload Report. BAW-1565 (Rev. 1), Babcock \& Wilcox, Lynchburg, Virginia, March 1980.

46. P. C. Childress et al., Irradiation of Two $17 \times 17$ Demonstration Assemblies in oconee 2, cycle 2-Reload Report. BAW-1424, Babcock \& Wilcox, Lynchburg, Virginia, January 1976.

47. A. E. Scherer $(C-E)$, Letter to R. O. Meyer (NRC), "Request for Information on 1980 Performance of C-E Fuel, "July' i4, 1981.

48. M. G. Andrews, H. R. Freeburn, and W. O. Wohlsen, "The Performance of Combustion Engineering Fuel in Operatirig PWRs," ANS Topical Meeting on Light Water Reactor Fuel Performance, Pcrtlard, Oregon, April-May 1979.

49. S. R. Pati, Gas Release and Microstructurzl Evaluation on One- and TwoCycle Fuel Rods from Calvert Cliffs-1. NPSD-75, Combustion Engineering, Inc., March 1979. (EPRI/C-E Program)

50. E. J. Ruzauskas, J. G. Schneider, and P. A. Van Saun, Examination of Calvert Cliffs 1 Test Fue? Assembly After Cycle 3, NPSD̄-87, Combustion Engineering, Inc., September 1979. (EPRI/C-E Program)

51. D. S. Kneppe1, Ex-Reactor Creep Behavior of Zircaloy-4 Tubing Used in Arkansas Nuclear One--Unit II Fuel Assemblies, NPSD-97, Combustion Engineering, Inc., October 1979. 
52. D. Franklin, H. Ocken, and T. 01dberg, LWR Core Materials Performance Program: Progress in 1979-1980, EPRI NP-1770-SR, Special Report, ETectric Power Research Institute, Palo Alto, Californic, March 1981.

53. Licensee Event Report No. 80-039/03L-0, Docket No. 50355, September 15, 1980.

54. Licensee Event Report No. 81-009/03L-0, Docket No. 50255, February 26, 1981.

55. Licensee Event Report №. 79-029/99X-0, Docket No. 50309, December 7, 1979.

56. Licensee Event Report No. 80-004/01T/1, Docket No. 50309, February 14, 1980.

57. Licensee Event Report No. 79-030/99X-0, Docket No. 50309, December 7, 1979.

58. C. A. Exarhos, Summary of ENC Fuel Performance Through December 31, 1980, XN-NF-81-09(P) Revision I, Exxon Nuclear Company, Richland, Washington, March 1981. This document is not publicly available because it contains proprietary information.

59. G. F. Owsley (ENC), Letter to M. Tokar (NRC), "Summary of ENC Fuel Exposure in 1980," June 2, 1981.

60. R. J. Williams et a1., Experience with BWR Fuel Through January 1981 , NEDE-24343-P, General Electric Company, San Jose, California, May 1981. This document is not publicly available because it contains proprietary information.

61. W. E. Baily, J. S. Armijo, J. Jacobson, and R. A. Proebstle, "BWR Fuel Performance," ANS Topical Meeting on Light Water Reactor Fuel Performance, Portiand, Oregon, Aprij-May 1979.

62. J. Skaritka and J. A. Iorii, Operational Experience with Westinghouse Cores (up to December 31,1980 , WCAP-8183, Rev. 10, Westinghouse Electric Corporation, Pittsburgh, Pennsylvania, May 1981.

63. R. S. Kaiser et a1., "High Burnup Experience in PWRs," ANS Topical Meeting on Light Water Reactor Fuel Performance, Portland, Oregon, ApriTMay 1979.

64. E. Roberts J. A. Iorii, and B. Argall, "Westinghouse Pressurized Water Reactor Fuel Development and Performance," Nuclear Energy 19(5):335-346 (October 1980).

65. EPRI Guide, Research Reports Center, Electric Power Research Institute, Palo Alto, California, Spring 1980. 
66. EPRI Guide, Research Reports Center, Electric Power Research Institute, Palo Alto, California, Summer 1980.

67. EPRI Guide, Research Reports Center, Electric Power Research Institute, Pato Alto, California, Fall 1980.

68. Atomic Energy of Canada Limited, Review of In-Reactor Zircaloy Corrosion and Crud Deposition Experience at AECL. EPRI NP-1254, Electric Power Research Institute, Palo Alto, California, December 1979.

69. Kraftwerk Union, A. G., and Combustion Engineering, Inc., Review of PWR Fuel Rod Waterside Corrosion Behavior. EPRI NP-1472, Electric Power Research Institute, Palo Alto, California, August 1980.

70. M. Tokar (NRC), Memorandum to M. W. Libarkin (Assistant Executive Director for Project Review, ACRS), "Report to ACRS Concerning NRR Efforts on Pellet/Cladding Interaction," November 14, 1979.

71. R. Riggs, Control Rod Guide Tube Wear in Operating Reactors (Operating Exper jence Report), NUREG-0641, U.S. Nuclear Regulatory Commission, Apri1 1980.

72. C. P. Yundt (Portland General Electric), Letter to R. H. Engelken (NRC), "Licensee Event Report No. 80-006/0IT-0," May 8, 1980. Docket No. 50344 (Trojan-1).

73. Portland General Electric, Letter to R. A. Ciark (NRC), "Preliminary Report on Trojan EOC-2 Fuel Examination," July 9, 1980. Docket No. 50344 (Trojan-1).

74. C. P. Yundt (Port]and General Electric), Letter to R. H. Engelken (NRC), "Follow-Up Report [to Licensee Event Report No. 80-006] Regarding the Damaged Fuel, Its Cause, and Corrective Action," August 18, 1980. Docket No. 50344 (Trojan-1).

75. "Early Results Summary: Trojan EOC-2 Fuel Examination," July 1980. Docket No. 50344 (Trojan-1). (EPRI supported on-site fuel examinations.)

76. Westinghouse Electric Corporation, Telex to M. Tokar (NRC), "Baffle Jetting," June 1980.

77. C. Goodwin, Jr. (Portland General Electric), Letter to R. A. Clark (NRC), Transmitting License Change Application 61, May 12, 1980.

78. M. Tokar (NRC), Note to R. Meyer (NRC), "Telecon with Trojan Re: Oral Fuel Surveillance Report," June 6, 1980.

79. R. 0. Meyer (NRC), Memorandum for R. A. Clark (NRC), "Trojan License Change Application and Cycle 3 Reload," June 20, 1980. 
80. N. C. Moseley (NRC), Memorandum to B. H. Grier et al. (NRC), "IE Circular No. 80-17--Fuel Pin Oamage Due to Water Jet from Baffle Plate Corner," Ju 1 y 21, 1980.

81. N. C. Moseley (NRC), Memorandum to B. H. Grier et al. (NRC), "IE Circular No. 80-13--Grid Strap Oamage in Westinghouse Fuel Assemb lies," May 23, 1980 .

82. J. Skaritka and J. A. Iorii, Operational Experience with Westinghouse Cores (up to December 31, 1979), WCAP-8183, Rev. 9, Westinghouse Electric Corporation, Pittsburgh, Pennsylvania, Apri门 1980.

83. Consolidated Edison Co., Letter to B. H. Grier (NRC), "Licensee Event Report No. 81-002/99X-0," January 15, 1981. Oocket No. 50247 (Indian Point-2).

84. Consolidated Edison Co., Letter to B. H. Grier (NRC), "Licensee Event Report No. 81-002/99X-1," March 20, 1981. Docket No. 50247 (Indian Point-2).

85. J. D. O'Toole (Consolidated Edison Company of New York, Inc.), Letter to B. H. Grier (NRC), "Indian Point Unit No.-2, Docket No. 50-247, LER-81001/99X-2," May 19, 1981.

86. M. Tokar (NRC), Letter to R. 0. Meyer (NRC), "Maine Yankee Fuel Failures," February 29, 1980.

87. R. H. Groce (Maine Yankee Atomic Power Company), Letter to R. W. Reid (NRC), "Maine Yankee Fuel Performance," March 10, 1980.

88. End-of-Cycle 4 Fuel and CEA Eddy Current Inspection Report; 1980 Ma ine Yankee Refueling Outage. CEN-129(M)-P (Proprietary), Combustion Engineering, Inc., Windsor, Connecticut, March 24, 1980. This document is not publicly available because it contains proprietary information.

89. Maine Yankee End-of-Cycle 4 Surmary of Fuel Inspection Results. CEN-131 (M) -P (Proprietary), Combustion Engineering, Inc., Windsor, Connecticut, March 1980. This document is not publicly available because it contains proprietary information.

90. "LER No. 80-004/0IT-1," LER Monthly Report (for April 1980), May 1980 (p. 40). Oocket No. $5030 \overline{9}$ (Maine Yankee).

91. R. E. Engel (GE), Letter to M. Tokar (NRC), "Corrosion Product Control," Oc tober 3, 1980.

92. L. S. Rubenste in (NRC), Memorandum for T. M. Novak (NRC), "Vermont Yankee Reload 7," Oc tober 27, 1980. 
93. L. S. Rubenste in (NRC), Memorandum for T. M. Novak (NRC), "Vermont Yankee Reload 7-Request for Supplemental Information Re: Waterside Corrosion Failures," December 5, 1980.

94. R. L. Smith (Vermont Yankee Nuclear Power Corporation), Letter to Office of Nuclear Reactor Regulation (NRC), "Supplemental Information to Vermont Yankee Reload No. 7 Submitta\}," November 21, 1980. (Docket No. 50271).

95. R. L. Smith (Vermont Yankee Nuclear Power Corporation), Letter to Office of Nuclear Reactor Regulation (NRC), "Clarification of the General Electric/Vermont Yankee Position on Vermont Yankee Fuel Failures," February $5,1981$.

96. L. DelGeorge (Commonwealth Edison), Letter to B. J. Youngblood (NRC), "LRG Working Paper Response, dated December 2, 1980," February 9, 1981.

97. "LER No. 80- /02L-0," LER Monthly Report (for October 1980), November 6, 1980 (p. 30). Oocket No. 50413 (Catawba-1).

98. "LER No. 80-035/99X-0," LER Monthly Report (for April 1980), May 1980 (p. 46). Docket No 50338 (North Anna-1).

99. "LER No. 80-011/01T-0," LER Monthly Report (for May 1980), June 4, 1980 (p. 89). Docket No. 5032T (Sequoyah-1).

100. "LER No. 80-014/01T-0," LER Monthly Report (for May 1980), June 4, 1980 (p. 95). Docket No. 50280 (Surry-1).

101. R. L. Gridley (GE), Letter to H. E. BTiss/J. A. Silady (Commonwealth Edison Company), "Quad Cities 1 Reload 5 Gadolinia Rods," November 11, 1980 .

102. W. V. Johnston ( RC), Memorandum to T. A. Ippolito (NRC), "Underpressurized Gadolinia Fuel Rods," December 4, 1980.

103. R. F. Janecek (Commonwealth Edison), Letter to Director of Nuclear Reactor Regulation (NRC), "Quad Cities Station Unit 1 Cycle 6, Operation per Provisions of 10 CFR 50.59, NRC Docket No. 50-254," November 25, 1980.

104. T. D. Murray (Toledo Edision), Letter to J. G. Keppler (NRC), "Reportable Occurrence 80-040," May 23, 1980. (Licensee Event Report No. 80040/03L-0; Docket No. 50346, Dav is Besse-1).

105. R. P. Crouse (Toledo Edison), Letter to R. W. Re id (NRC), "Supplement to Oavis-Besse Nuclear Power Station, Unit 1, Cycle 2-Reload Report: Review of Repaired Fuel Assembly," July 10, 1980. Docket No. 50346. 
106. R. P. Crouse (Toledo Edison), Letter to T. M. Novak (NRC), "Responses to Questions Concerning Fue1 Assemb ly Holddown Springs for Davis-Besse Nuc Tear Power Station, Unit 1, (NRC Letter, July 1, 1980), "JuTy 18, 1980. Docket No. 50346 .

107. W. 0. Parker, Jr. (Duke Power), Letter to J. P. O'Reilly (NRC), "Reportable Occurrence Report R0-269/80-15," June 6, 1980. (Licensee Event Report No. 80-015/01T-1; Docket No. 50269; Oconee-1).

108. "LER No. 80-015/01X-1," LER Month ly Report (for January 1981), February 4, 1981 (p. 40). Docket No. 50269 (Oconee-1).

109. "LER 80-015/01T-0," LER Monthly Report (for July 1980), July 31, 1980 (p. 52). Docket No. 50269 (Oconee-1).

110. L. S. Rubenstein (NRC), Memorandum for T. M. Novak (NRC), "B\&W Fue 1 Assembly Holddown Spring Failures," December 30, 1980.

111. L. S. Rubenstein (NRC), Memorandum for R. W. Reid (NRC), "B\&W Fuel Assembly Hold-Down Spring Damage--Questions to Licensees," June 2, 1980.

112. W. 0. Parker, Jr., (Duke Power Company), Letter to H. R. Denton (NRC), "Safety Evaluation of UHI Holddown Assembly Springs," November 18, 1980. McGuire Nuclear Station, Docket Nos. 50369 and 50370 .

113. N. C. Moseley (NRC), Memorandum to J. R. Shea (NRC), "Ohi Unit 1," May 22, 1980.

114. M. Tokar (NRC), Note for W. V. Johnston ( "C), "W Spring Failures," August 8,1980 .

115. U.S. Nuclear Regulatory Commission, Licensed Operating Reactors, Status Summary Report, Data as of 12-31-80. NUREG-0020, Vo1. 5, No. 1, January 1981.

116. W. V. Johnston (NRC), Memorandum for B. J. Youngb lood (NRC), "MCGuire UHI Holddown Assembly Spring Question," October 6, 1980.

117. Office of Management and Program Analysis, U.S. Nuclear Regulatory Commission, Licensed Operating Reactors, Status Summary Report, Data as of 8-31-81. NUREG-0020, Vo1. 5, No. 9, September 1981.

118. U.S. Nuclear Regulatory Commission, Nuclear Power Plants, Construction Status Report, Data as of 12-31-80. NUREG-0030, Vol. 4, April 1981.

119. "LER No. 80-009/03X-1," LER Monthly Report (for December 1980), January 7, 1981 (p. 3). Docket No. 50368 (Arkansas-2). 
120. "LER No. 80-082/03L-0," LER Monthly Report (for January 1981), February 4, 1981 (p. 13). Docket No. 50324 (Brun swick-2).

121. "LER No. 79-099/03L-0," LER MonthTy Report (for February 1980), March 3, 1980 (p. 16). Docket No. 50324 (Brun swick-2).

122. A. C. Tollison, Jr. (Carolina Power \& Light Company), Letter to J. P. 0'Reilly (NRC), "Brunswick Steam Electric Plant, Unit 2, Docket No. 50-324, License No. DPR-62, Licensee Event Report 2-80-111," January 7,1981 . (LER No. 80-111/03L-0).

123. "LER No. 79-109/03L-0," LER Monthly Report (for February 1980), March 3, 1980 (p. 26). Docket No. 50302 (Crysta? River-3).

124. "LER No. 80-042/03L-0," LER Monthly Report (for Novenber 1980), December 11,1980 (p. 21). Docket No. 50302 (Crystal River-3).

125. "LER No. 80-009/03L-0," LER Monthly Report (for April 1980), May 1980 (p. 16). Docket No. 50302 (Crystal River-3).

126. J. A. Hancock (Florida Power), Letter to J. P. O'Reilly (NRC), "Licensee Event Report 80-052/03L-0," January 5, 1981. Docket No. 50302 (Crysta1 River-3).

127. M. Tokar (NRC), Memorandum for R. 0. Meyer (NRC), "Repeated Violations of I-131 Coolant Activity Limit at Crystal River 3," May 22, 1980.

128. "LER No. 80-089/03L-0," LER Monthly Report (for February 1981), March 2, 1981 (p. 29). Docket No. 50346 (Dav is-Besse-1).

129. T. D. Murray (Toledo Edison), Letter to J. G. Keppler (NRC), "Reportable Occurrence 80-089, Davis-Besse Nuclear Power Station Unit 1, Date of Occurrence: December 3, 1980," January 2, 1981. (LER No. 80-089/03L-0).

130. "LER No. 80-039/03L-0," LER Monthly Report (for January 1981), February 4, 1981 (p. 49). Docket No. 50335 (St. Lucie-1).

131. D. C. Trimble (Arkansas Power \& Light Company), Letter to K. V. Seyfrit (NRC), "Arkansas Nuc lear One-Unit 1, Docket No. 50-313, License No. DPR-51, Licensee Event Report 80-006/04L-0 (File: 0520), "Apri1 16, 1980.

132. D. C. Trimble (Arkansas Power \& Light Company), Letter to K. V. Jeyfrit (NRC), "Arkansas Nuclear One-Unit 1, Docket No. 50-313, License No. DPR-51, Licensee Event Report No. 80-027/04L-0, (File: 0520)," August 22, 1980. 
133. 0. C. Trimble (Arkansas Power \& Light Company), Letter to K. V. Seyfrit (NRC), "Arkansas Nuclear One-Un it 1, Docket No. 50-313, License

No. DPR-51, Licensee Event Report No. 80-027/03X-1, (File: 0520), " October $16,1980$.

134. "LER No. 80-027/04 X-1," LER Monthly Report (for November 1980), December $11,1980(p .1)$. Oocket No. 50313 (Ark ansas-1).

135. G. A. Vissing (NRC), Memorandum for H. Oenton, et al. (NRC), "Oaily Highlight," February 9, 1981.

136. Babcock \& Wilcox Company, Continuous Fission-Product Monitor System at Oyster Creek, EPRI NP-1577, Electric Power Research Institute, Pa10 ATto, California, 1980.

137. "LER No. 80-006/03L-0," LER Monthly Report (for October 1980), November 6, 1980 (p. 55). Docket No. 50409 (La Crosse).

138. "LER No. 80-007/03L-0," LER Month?y Report (for October 1980), November 6, 1980 ( $p .55)$. Docket No. 50409 (La Crosse).

139. F. Linder (Dairyland Power Cooperative), Letter to J. G. Keppler (NRC), "Oairyland Power Cooperative, La Crosse Boiling Water Reactor (LACBWR) Provisiona 1 Operating Licensee No. OPR-45, Reportable Occurrences No. 80-06 and 80-07," September 12, 1980.

140. "LER No. 80-070/01L-0," LER Monthly Report (for October 1980), November 6, 1980 (p. 15). Docket No. 50259 (Browns Ferry-1).

141. "LER No. 80-037/01L-0," LER Monthly Report (for November 1980), December 11, 1980 (p. 9) Docket No. 50260 (Browns Ferry-2).

142. "LER No. 80-002/03L-0," LER Monthly Report (for March 1980), April 2, 1980 (p. 68). Docket No. 50219 (Oyster Creek-1).

143. "LER No. 80-002/03L-1," LER Monthly Report (for Ju ly 1980), Ju 1y 31,1980 (p. 54). Docket No. 50219 (Oyster Creek-1).

144. "LER No. 80-013/01T-0," LER Monthly Report (for May 1980), June 4, 1980 (p. 35). Docket No. 50331 (Duane Arnold).

145. "LER No. 80-041/-1T-0," LER Monthly Report (for November 1980), December 11,1980 ( $p .10)$. Docket No. 50260 (Browns Ferry-2).

146. Commonwea1th Edison Co., Letter to NRC, "LER 80-024," October 8, 1980.

147. "LER No. 80-017/01T-0," LER Month ly Report (for February 1980), March 3, 1980 (p. 63). Docket No. 50338 (North Anna-1). 
148. "LER No. 80-039/01T-0," LER Monthly Report (for January 1981), February 4, 1981 (p. 34). Docket No. 50305 (Kewaunee-1).

149. "LER No. 80-046/03L-0," LER Monthly Report (for July 1980), Ju ly 31, 1980 (p. 22). Docket No. 50346 (Dav is-Besse-1).

160. W. G. Counsil (Northwest Utilities), Letter to D. M. Crutchfield (NRC), "Haddam Neck Plant Inter im Report on Fuel Rod Failures," January 19, 1981. Docket No. 50231 .

150. "LER No. 79-/02L-," LER Monthly Report (for February 1980), March 3, 1980 (p. 85). Docket No. 50390 (watts 8ar-T).

151. D. A. Powers (NRC), Memorandum for R. 0. Meyers (NRC), "Guide Tube Wear Input for the Annua1 Report," November 17, 1980.

152. R. P. Den ise (NRC), Memorandum for S. A. Varga (NRC), "Request for Additiona? Information for North Anna, Unit 2," April 7, 1980.

153. R. P. Den ise (NRC), Memorandum for S. A. Varga (NRC), "Request for Additional Information for Diablo Canyon, Units 1 and 2," Apri1 7, 1980.

154. R. P. Den ise (NRC), Memorandum for S. A. Varga (NRC), Request for Additional Inf ormation for McGuire, Units 1 and 2," April 7, 1980.

155. R. P. Den ise (NRC), Memorandum for S. A. Varga (NRC), "Request for Additional Information for Sequoyah, Units 1 and 2, "April 7, 1980.

156. R. P. Den ise (NRC), Memorandum for S. A. Varga (NRC), "Updated Safety Evaluation Input for North Anna, Unit 2," February 7, 1980.

157. R. P. Den ise (NRC), Memorandum for S. A. Varga (NRC), "Updated Safety Evaluation Input for Diablo Canyon, Units 1 and 2," April 3, 1980.

158. R. P. Den ise (NRC), Memorandum for S. A. Varga (NRC), "Updated Safety Evaluation Input for Salem, Unit 2," March 20, 1980.

159. M. Tokar (NRC), Note for R. 0. Meyer (NRC), "Conference Call on Haddam Neck Batch 8 Fue? Report," September 2, 1980.

160. W. G. Counsil (Northwest Utilities), Letter to D. M. Crutchfield (NRC), "Haddam Neck Plant Interim Report on Fuel Rod Failures," January 19, 1981. Dock et No. 50231 .

161. R. H. Graves (Connecticut Yankee Atomic Power Company), Letter to B. Grier (NRC), "Inf ormational Report, Core 9 Fuel Inspection," July 16, 1980. (Docket 50213)

162. IE Information Notice No. 80-02, "8 $\times 8$ R Water Rod Lower End Plug Wear," January 25, 1980. 
163. J. S. Charnley (General Electric), Letter to T. A. Ippolito (NRC), "Water Rod Lower End P1 Jg Inspection Results," july 28, 1980. This document is not publicly available because it contains proprietory information.

164. D. G. Franklin, "Economic Incentives fo Improved Core Materials Performance," Trans. Am. Nuc 1. Soc. 35:201-202, November 1990.

165. N. Eickelpasch et al., "BWR iontrol Rods: Operational Experiences and Postirradiation Examinations," Trans. Am. Nucl. Soc. 39:394-395, November-December 1981.

166. Trans. Am. Nuc 1. Soc. $34: 79-83,90-92,557-566,573-579,591-601$, $633-639,714-717,789-797$, and 864-87?, June 1980.

167. Trans. Am. Nuc 1. Soc. 35:57-62, 194-200, 270-277, and 412-414, November 1980.

168. Trans. Am. Nuc 1. Soc. 38:624-626, June 1981.

169. G. R. Thomas, "Overview--Significant Aspects of TMI-2 Core Material Performance," Trans. Am. Nuc 1. Soc. 35:194-196, November 1980.

170. J. E. Hanson, ed., "TMI-2 Planning Group 7.4, Fuel Experiments and Examination; First Draft of 7.4 Plan," EG\&G Idaho, Inc:, July 1980.

i71. G. R. Bond, et al "Plans for the Examination of the TMI-2 Core," Trans. Am. Nuc 1. Soc. 35:200, November 1980.

172. M. L. Picklesimer, "An Estimate of the Damage to the TMI-2 Core," Trans. Am. Nuc l. Soc. 35:196-197, November 1980.

173. Nuclear Safety Analys is Center, Indexed Bibliography of TMI-2 Documents in NSAC Working File; Accumulated Through December 31, 1979. NSACBib. 4. Electric Power Research Institute, Palo Alto, California, January 1980.

174. H. S. Rosenbaum (compiler), Demonstration of Fuel Resistant to PelletCladding Interaction, Phase 2--Third Semiannual Report January-June 1980 . GEAP-25163-3, General Electric Company, San Jose, California, September 1980.

175. H. S. Rosenbaum (compiler), Demonstration of Fuel Resistant to PelletCladding Interaction, Phase 2--Fourth Semiannual Report, JulyDecember 1980, GEAP-25163-4, General Electric Company, San Jose, California, March 1981.

176. C. E. Crouthamel and M. D. Freshley, Fuel Performance Improvement Program, Semiannual Progress Report, October 1980-March 1981, 00E/ET/ 34215-21, Apri1 1981. 
177. C. E. Crouthamel and M. D. Freshley, Fuel Performance Improvement Program, Semiannual Progress Report, April 1980-September 1980, D0E/ET/ 34215-19, October 1980.

178. C. E. Crouthamel and M. D. Freshley, Fuel Performance Improvement Program, Semiannual Progress Report, October 1979-March 1980, DOE/ET/ 34215-16, ApriT 1980.

179. Peter M. Lang, "Future Trends in LWR Fuel to Improve Uranium Utilization," Trans. Am. Nucl. Soc. 30:274-275, November 1978.

180. Adrian Roberts and Howard Dcken, "Improving Nuclear Fuel Reliability," EPRI Journal, pp. 75-79, October 1978.

181. Babcock \& Wilcox Company and Sacramento Municipal Utility District, Axial Blanket Fuel Design and Demonstration, First Semi-Annual Progress Report, January-September 1980, D0E/ET/34020-1 (BAW-1643-1), Babcock \& Wi Icox Company, Lynchburg, Virginia, November 1980.

182. G. C. Hopkins (compiler), Improved Uranium Utilization Program, Phase 1 (First Semiannual Report September 1979-March 1980). GEAP-25332-1, General Electric Company, San Jose, Calífornia, November 1980.

183. U. Decher, Evaluation and Demonstration of Methods for Improved Fuel Utilization (First Semi-Annua) Progress Report: September 1979-March 1980), CO0-34010-1 (CEND-382), June 1980.

184. C. W. Bagnal et al., Use of Gadolinium in PWR Extended-Burnup Fuel Cycles. CEND-391, Combustion Engineering, Inc., Windsor, Connecticut, June 1981.

185. Westinghouse Electric Corporation and Virginia Electric and Power Company, Extended Fuel Burnup Demonstration Program, First Technical Progress Report for the Period from June 1979 to December 1980. WCAP-9883, Westinghouse Electric Corporation, Pittsburgh, Pennsylvania, March 1981. 


\section{DISTRIBUTION}

No. of

Copies

\section{DFFSITE}

A. A. Churm

DOE Patent Division

$9300 \mathrm{~S}$. Cass Avenue

Argonne, IL 60439

295 Nuclear Regulatory Commission Division of Technical Information and Document Contro? 7920 Norfolk Avenue Bethesda, MD 20014

2 DOE Technical Information Center

4 C. H. Berlinger

Chief, Core Performance Branch Office of Nuclear Reactor Regulation

U.S. Nuclear Regulatory Commission Washington, DC 20555

R. 0. Meyer

Core Performance Branch

Division of Systems Integration

Office of Nuclear Reactor

Regulation

U.S. Nuclear Regulatory

Commission

Washington, DC 20555

M. Tokar

Core Performance Branch

Division of Systems Integration

Office of Nuc lear Reactor

Regulation

U.S. Nuc lear Regulatory Commission

Washington, DC 20555
No. of

Copies

ONSITE

41 Pac if ic Northwest Laboratory

W. J. Bajley (12)

J. 0. Barner

W. D. Bennett

G. E. Beyer

M. E. Cunningham

M. D. Freshley

R. L. Goodman

R. J. Guenther

C. R. Hann

K. H. Rising

D. D. Lanning

$R$. R. Lewis

R. K Marshall

C. L. Mohr

C. Nealley

F. E. Panisko

L. J. Parchen

W. N. Rausch

G. E. Russcher

R. A. Scoggin

N. J. Wildung

R. E. Wiliford

C. L. Wilson

Technical Information (5)

Publishing Coordination (2) (KC) 



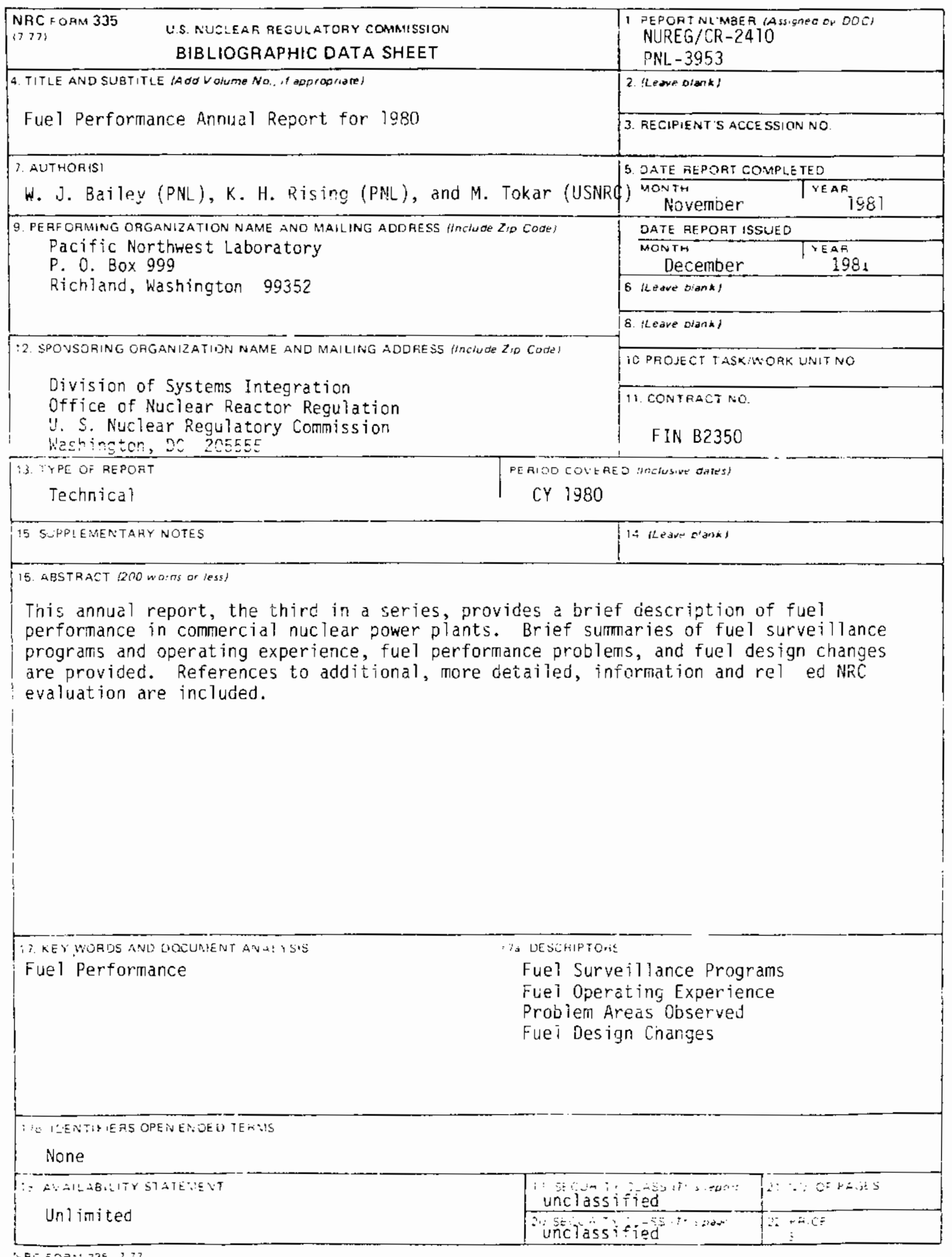


